\title{
Antihypertensive Properties of Plant Protein Derived Peptides
}

\author{
Anne Pihlanto and Sari Mäkinen
}

Additional information is available at the end of the chapter

http://dx.doi.org/10.5772/54565

\section{Introduction}

Cardiovascular diseases (CVD) are a major health problem in the industrialized countries, representing the main cause of death in the world. It is estimated that 17 million people globally die of CVD every year and these diseases are responsible for more than half of all deaths in Europe [1]. Therefore, primary prevention is becoming an increasing part of public health strategies aimed at reducing societal burden due to CVD-related morbidity and mortality worldwide. There are several behavioural factors such as tobacco use, ethanol consumption, unhealthy diet and physical inactivity that can lead to hypertension, hyperlipidemia, diabetes, overweight and obesity, and thereby contribute to CVD development. The World Health Organisation emphasises the importance of improved nutrition as means of controlling the expected rise in global CVD incidence over the next decades.

Angiotensin I-converting enzyme (ACE: EC 3.4.15.1) is a peptidyldipeptide hydrolase that plays an important physiological role in both the regulation of blood pressure and cardiovascular function [2] through two different reactions. First, ACE catalyzes the hydrolysis of angiotensin I, an inactive decapeptide, to angiotensin II, a powerful vasoconstrictor and salt-retaining octapeptide. Thus, ACE-inhibition has a hypotensive effect. Secondly, ACE catalyzes the inactivation of the vasodilator bradykinin that regulates different biological processes including vascular endothelial nitric oxide (NO) release [3].

Oxidative stress has a well documented role in CVD development. Oxidative stress is defined as the situation characterized by increased generation of free radicals (reactive oxygen species, ROS), resulting in increased oxidative damage of biological structures. Within the cell, physiologic levels of some ROS are involved as key intermediates in signalling pathways to maintain basal cellular functions. In contrast, when ROS are 
generated in the absence of a physiological stimulus, small-molecule antioxidants are depleted, or antioxidant enzymatic systems are overwhelmed. This leads to a net increase in biologically active ROS and oxidant stress ensues. In blood vessels, oxidant stress has deleterious consequences for basal vascular function. Then, the cellular mechanisms that result in vascular redox imbalance leading to an increase in oxidant stress are implicated in the pathogenesis of vascular disease [4].

The search for dietary compounds that prevent the development of CVD is deemed crucial to tackle this major health problem worldwide, and recent observational studies and clinical trials have suggested that increased protein consumption, particularly from plant sources, might reduce blood pressure and prevent CVD. Recently, interest has been emerging to identify and characterize bioactive peptides from plant and animal sources. Bioactive peptides are considered specific protein fragments that are inactive within the sequence of the parent protein. After they are released they may exert various physiological functions. The type of bioactive peptides generated from a particular protein is dependent on two factors: (a) the primary sequence of the source protein and (b) the specificity of the enzyme(s) used to generate such peptides. The hydrolysis of plant proteins has led to the production of a variety of biologically active peptides, such as opioid, antihypertensive, antioxidative, immunomodulatory or antimicrobial peptides [5, 6]. Bioactivity of peptides depend on the structure, however, the structure activity relationship is not yet fully understood for all biological activities described. This present paper focuses on the peptides beneficial to CVD derived from plant proteins.

\section{Biological activities of plant proteins}

Potato tuber proteins are classified into three major groups: patatins, protease inhibitors, and other proteins. Patatin is the major storage protein and an allergen for some people. The second major potato tuber storage protein is a diverse group of low molecular weight protease inhibitors [7]. The majority of the patatin and proteinase inhibitor isoforms possess enzymatic and inhibitory activities, respectively, which might be of physiological relevance. Activities are associated with the defense mechanisms of potato against pathogens and they inhibit a variety of proteases and some other enzymes, for example invertase [8]. Low molecular weight antimicrobial potato peptides from potato tubers have recently been reported to exhibit antibiotic/antifungal activity also against human pathogenic fungal and microbial strains [9]. The broad phospholipase activity of patatin has been characterized and documented rather extensively $[10,11]$. The results indicate that the patatin-related enzymes are, in addition to fat metabolism, involved in the stress responses and signal transduction in the potato tubers. Patatin has also been shown to possess antioxidant or antiradical activity. Liu and colleagues [12] found that purified patatin exert antioxidant or antiradical activity in various in vitro tests, such as radical, scavenging activity assay and protection against hydroxyl radical-induced calf thymus DNA damage. Potato protein hydrolysates showed antioxidant activity [13] and enhanced oxidative stability of soybean oil emulsions [14]. Two peptides derived from metallocarboxypeptidase inhibitor and lipoxygenase 1 
were identified. Potatoes may have a role in controlling appetite and therefore weight gain, by contributing to satiety. Gastrointestinal hormones such as cholecystokinin (CCK) are key factors in the regulation of food intake and maintaining energy homeostasis. Hill and colleagues [15] reported reduced energy intake and increased CCK release, when protease inhibitors extracted from potatoes were tested in 11 lean subjects.

The protein content of defatted rapeseed meal is high, approximately $32 \%$, making it a potential food ingredient. Rapeseed protein has recently been demonstrated to be of high nutritional value in human subjects and substituting Cys-rich rapeseed protein, for milk protein prevented the early onset of insulin resistance, similar to those achieved by manipulating dietary fat and carbohydrates in a rat model [16, 17]. Flaxseed and its defatted meal contain high amounts of proteins, which are comparable in amino acid composition to food proteins like soy, with a preponderance of basic and branch-chain amino acids. The high Cys and Met content can boost the body's antioxidant levels, potentially stabilising DNA during cell division and reducing risk of certain forms of colon cancer [18]. Yet, there are only few studies examining rapeseed and flaxseed meals as source of bioactive peptides to enhance the value of these rapeseed and flaxseed industry by-products.

Legumes could represent valuable tools to prevent CVD, in addition to constitute an important source of dietary proteins ( 18-40\%), dietary fibre, minerals and vitamins. Epidemiological studies have provided consistent evidence of the inverse relationship between legume consumption and the incidence of CVD. The majority of studies that have evaluated the hypocholesterolemic effects of legume consumption examined soybeans [19]. In addition, the meta-analysis showed that diet rich in legumes, such as a variety of beans, peas, and some seeds other than soy decreases total and low-density lipoprotein (LDL) cholesterol [20]. Different legumes have been identified as sources of ACE-inhibitory and antioxidative peptides, mainly soybean [21-24], chickpea and pea [25-28].

Cereal grains contain relatively little protein compared to legume seeds, with an average of about $10-12 \%$ of dry weight. Storage proteins account for about $50 \%$ of the total protein in mature cereal grains and have important impacts on their nutritional quality for humans and livestock and on their functional properties in food processing. Proteins can be separated into albumin, globulin, prolamin (hordein) and gluten fractions as described by [29]. The prolamins are characterized by their high content of Pro and Glu and low content of Lys and Trp. Alcohol-soluble endosperm proteins (prolamins) from some cereals (e.g. wheat, barley, and rye) give origin upon proteolytic digestion to biologically active antinutritional peptides able to adversely affect in vivo the intestinal mucosa of coeliac patients, whereas prolamins from other cereals (e.g. maize and rice) do not [30]. A large deal of cereal proteins originates from by-products following production of starch, malting or brewing industry. For example, $\alpha$-zein protein, derived from corn starch production, is rich in Pro and hydrolysis by thermolysin liberates ACE-inhibitors [31]. Wheat proteins are also source of opioid peptides [32] and tryptic hydrolysate of rice proteins yields the immunomodulatory peptide, oryzatensin [33]. 


\subsection{Production of peptides}

ACE-inhibitory peptides have been produced by enzymatic hydrolysis and microbial fermentation of food proteins. In addition, solvent extraction has been used to isolate ACEinhibitory activity from plant materials, such as mushrooms, broccoli and buckwheat [6]. The ACE-inhibitory potency is expressed as the $\mathrm{IC}_{50}$ value (inhibitor concentration leading to $50 \%$ inhibition), being used to estimate the effectiveness of different hydrolysates and peptides. The most common way to produce bioactive peptides is through enzymatic hydrolysis of whole protein molecules. The specificity of enzyme and process conditions influence the peptide composition of hydrolysates and thus their activities.

Generally, enzymatic hydrolysis is widely applied to upgrade functional features (such as emulsifying properties of hydrolysed protein) and nutritional properties of proteins [34-36]. It has been reported that additional advantage of hydrolysis can be the development of hydrophobicity since proteolysis unfolds the protein chains. The cleavage of peptide bonds enhances levels of free amino and carboxyl groups resulting in enhanced solubility. Therefore, hydrolysis can increase or decrease the hydrophobicity, which mostly depends on the nature of the precursor protein and molecular weight of the generated peptides [34]. Moreover, hydrolysis leads to production of small bioactive peptides [35] and bitterness of peptides of below $1000 \mathrm{Da}$ is much less than fractions with a higher molecular mass [36]. However, it has been reported that extensive hydrolysis could adversely affect functional properties of peptides [37]. Some factors to consider in producing bioactive peptides include hydrolysis time, degree of hydrolysis of the proteins, enzyme-substrate ratio, and pretreatment of the protein prior to hydrolysis. For example, thermal treatment of proteins can enhance enzymatic hydrolysis [38] possibly by increasing enzyme-protein interactions due to thermal-induced unfolding of the proteins.

According to the literature, enzymatic hydrolysis has been the main process for producing ACE-inhibitory and antioxidative peptides from food proteins. Use of exogenous enzymes is preferred in most cases over the autolytic process (i.e., use of endogenous enzymes present in the food source itself), due to the shorter time required to obtain similar degree of hydrolysis as well as better control of the hydrolysis to obtain more consistent molecular weight profiles and peptide composition [39-45]. Industrial food-grade proteinases such as Alcalase, Flavourzyme, and Protamex derived from microorganisms, as well as enzymes from plant (e.g. Papain) and animal sources (e.g., pepsin and trypsin), have been widely used in producing ACE-inhibitory and antioxidative peptides. The serine type endoprotease Alcalase, has produced the highest ACE-inhibitory activities in vitro in case of several plant proteins (Table 1).

Alcalase digests of rapeseed, canola, flaxseed, sunflower seed protein, legumes as well as and mung and chick beans showed high potency for ACE inhibition [41, 43-48]. Moreover, Alcalase digestion increased the ACE inhibition of the protein-rich by-product fraction from potato starch industry, potato tuber liquid fraction [13]. The IC 50 -values were ranged between 0.020 and $0.64 \mathrm{mg}$ protein $/ \mathrm{ml}$, which are similar to those reported for milk whey and casein hydrolysates [5, 41, 45-47,49]. Mäkinen and colleagues [50] reported that 


\begin{tabular}{|c|c|c|c|c|c|c|c|}
\hline \multirow{2}{*}{$\begin{array}{l}\text { Source } \\
\text { protein }\end{array}$} & \multirow{2}{*}{$\begin{array}{l}\text { Enzyme or } \\
\text { other process } \\
\text { conditions }\end{array}$} & \multirow{2}{*}{\begin{tabular}{|l} 
ACE \\
inhibition
\end{tabular}} & \multicolumn{2}{|c|}{ Identified peptides } & \multicolumn{2}{|c|}{ In vivo response } & \multirow[t]{2}{*}{ Ref } \\
\hline & & & Sequences & $\begin{array}{l}\text { IC } C_{50} \text { value } \\
(\mu \mathrm{M})\end{array}$ & $\begin{array}{l}\text { Dose } \\
\text { administratio } \\
\text { n model }\end{array}$ & \begin{tabular}{|l|} 
Response $(\Delta$ \\
SBP \\
mmHg) \\
\end{tabular} & \\
\hline $\begin{array}{l}\text { Sweetpotato } \\
\text { tuber } \\
\text { protein } \\
\text { isolate }\end{array}$ & $\begin{array}{l}\text { Thermoase PC } \\
\text { 10F, Protease S } \\
\& \text { Proleather } \\
\text { FG-F } \\
\end{array}$ & 0.018 & \begin{tabular}{|l} 
ITP \\
IIP \\
GQY \\
STYQT \\
\end{tabular} & \begin{tabular}{|l}
9.5 \\
80.8 \\
52.3 \\
300.4 \\
\end{tabular} & $\begin{array}{l}500 \mathrm{mg} / \mathrm{kg} \\
\text { hydrolysate, } \\
\text { oral, SHR }\end{array}$ & -30 after $8 h$ & [121] \\
\hline $\begin{array}{l}\text { Sweetpotato } \\
\text { tuber } \\
\text { defensin }\end{array}$ & Trypsin & 0.190 & \begin{tabular}{|l|} 
GFR \\
FK \\
IMVAEAR \\
GPCSR \\
CFCTKPC \\
MCESASSK \\
\end{tabular} & \begin{tabular}{|l|}
94.25 \\
265.43 \\
84.12 \\
61.67 \\
1.31 \\
75.93 \\
\end{tabular} & & & [118] \\
\hline $\begin{array}{l}\text { Sweet } \\
\text { potato tuber } \\
\text { Thioredoxin } \\
\mathrm{h}\end{array}$ & Trypsin & 0.152 & \begin{tabular}{|l|} 
EVPK \\
VVGAK \\
FTDVDFIK \\
MMEPMVK \\
\end{tabular} & $\begin{array}{l}1.73 \\
1.14 \\
0.42 \\
1.03\end{array}$ & & & [119] \\
\hline $\begin{array}{l}\text { Sweetpotato } \\
\text { tuber } \\
\text { Trypsin } \\
\text { inhibitor }\end{array}$ & Pepsin & 0.188 & \begin{tabular}{|l|} 
HDHM \\
LR \\
SNIP \\
VRL \\
TYCQ \\
GTEKC \\
RF \\
VKAGE \\
AH \\
KIEL \\
\end{tabular} & \begin{tabular}{|l}
276.2 \\
746.4 \\
228.3 \\
208.6 \\
2.3 \\
275.8 \\
392.2 \\
141.56 \\
523.5 \\
849.7 \\
\end{tabular} & & & [120] \\
\hline Yam tuber & \begin{tabular}{|l|} 
Powdered yam \\
product, \\
alcohol- \\
insoluble-solids \\
Water extract \\
$(15 \%$ protein $)$ \\
Heat treated \\
$\left(90^{\circ} \mathrm{C}\right)$ water \\
extract \\
Dioscorin, \\
lyophilized yam \\
powder \\
Storage protein \\
ion-exhange \\
chromato- \\
graphy \\
Pepsin \\
hydrolysate \\
\end{tabular} & \begin{tabular}{|l} 
ND \\
\\
\\
\end{tabular} & & & $\begin{array}{l}60 \mathrm{mg} / \mathrm{kg} \\
\text { oral, SHR } \\
154 \mathrm{mg} / \mathrm{kg} \\
\text { oral, SHR } \\
154 \mathrm{mg} / \mathrm{kg} \\
\text { oral, SHR } \\
140 \mathrm{mg} \text { daily } \\
\text { oral, human } \\
40 \mathrm{mg} / \mathrm{kg} \\
\text { oral, SHR } \\
40 \mathrm{mg} / \mathrm{kg} \\
\text { oral, SHR }\end{array}$ & $\begin{array}{l}-32.4 \text { after } \\
6 \mathrm{~h} \\
-30.3 \text { after } \\
4 \mathrm{~h} \\
-23.87 \text { after } \\
4 \mathrm{~h} \\
\\
-6.52 \text { after } \\
2 \text { weeks } \\
-27.7 \text { after } 9 \\
\text { days } \\
-32.8 \text { after } 8 \\
\text { hours }\end{array}$ & [123] \\
\hline
\end{tabular}




\begin{tabular}{|c|c|c|c|c|c|c|c|}
\hline \multirow{2}{*}{$\begin{array}{l}\text { Source } \\
\text { protein }\end{array}$} & \multirow{2}{*}{$\begin{array}{l}\text { Enzyme or } \\
\text { other process } \\
\text { conditions }\end{array}$} & \multirow{2}{*}{\begin{tabular}{|l} 
ACE \\
inhibition
\end{tabular}} & \multicolumn{2}{|c|}{ Identified peptides } & \multicolumn{2}{|c|}{ In vivo response } & \multirow[t]{2}{*}{ Ref } \\
\hline & & & Sequences & $\begin{array}{l}\text { IC } \mathrm{C}_{50} \text { value } \\
(\mu \mathrm{M})\end{array}$ & \begin{tabular}{|l|} 
Dose \\
administratio \\
n model
\end{tabular} & \begin{tabular}{|l|} 
Response $(\Delta$ \\
SBP \\
mmHg) \\
\end{tabular} & \\
\hline Potato tuber & \begin{tabular}{|l|} 
Autolysed \\
protein extract \\
Alcalase digest \\
of potato tuber \\
liguid fraction \\
\end{tabular} & $\begin{array}{l}0.36 \\
0.018\end{array}$ & & & & & $\begin{array}{l}{[50]} \\
{[13]}\end{array}$ \\
\hline $\begin{array}{l}\text { Apios } \\
\text { Americana } \\
\text { Medikus } \\
\text { tuber }\end{array}$ & $\begin{array}{l}\text { Water extract } \\
\text { (rich in proline) }\end{array}$ & 127 & & & $\begin{array}{l}200 \mathrm{mg} / \mathrm{kg} \\
\text { oral, SHR }\end{array}$ & $\begin{array}{l}-25 \text { after } 0.5 \\
\text { and } 1 \mathrm{~h}\end{array}$ & [124] \\
\hline $\begin{array}{l}\text { Rapeseed } \\
\text { protein }\end{array}$ & $\begin{array}{l}\text { Pepsin } \\
\text { Subtilisin }\end{array}$ & $\begin{array}{l}0.16 \\
0.16\end{array}$ & $\begin{array}{l}\text { VWIS } \\
\text { VW } \\
\text { IY } \\
\text { RIY }\end{array}$ & $\begin{array}{l}30 \\
1.6 \\
3.7 \\
28\end{array}$ & $\begin{array}{l}500 \mathrm{mg} / \mathrm{kg} \\
\text { hydrolysate, } \\
12.5 \mathrm{mg} / \mathrm{kg} \\
7.5 \mathrm{mg} / \mathrm{kg} \\
7.5 \mathrm{mg} / \mathrm{kg} \\
7.5 \mathrm{mg} / \mathrm{kg} \\
\text { oral, SHR } \\
\end{array}$ & $\left|\begin{array}{l}-6.8 \text { after } 4 h \\
-15.5 \text { after } 4 h \\
-12.5 \text { after } 2 h \\
-10.8 \text { after } 2 h \\
-9.8 \text { after } 2 h \\
-11.3 \text { after } 4 h\end{array}\right|$ & {$[125]$} \\
\hline $\begin{array}{l}\text { Rapeseed } \\
\text { protein }\end{array}$ & \begin{tabular}{|l|} 
Alcalase \\
Peptide fraction \\
from affinity \\
purification \\
Alcalase
\end{tabular} & $\begin{array}{l}0.038 \\
0.25 \times 10^{-3} \\
\\
0.020\end{array}$ & & & & & {$\left[\begin{array}{l}{[45]} \\
{[47]}\end{array}\right.$} \\
\hline $\begin{array}{l}\text { Canola } \\
\text { meal, } \\
\text { defatted }\end{array}$ & $\begin{array}{l}\text { Heat treatment } \\
\text { and Alcalase }\end{array}$ & 0.027 & $\begin{array}{l}\text { VSV } \\
\text { FL }\end{array}$ & $\begin{array}{l}0.15 \\
1.33\end{array}$ & & & {$[46]$} \\
\hline $\begin{array}{l}\text { Flaxseed } \\
\text { protein }\end{array}$ & $\begin{array}{l}\text { Trypsin \& } \\
\text { Pronase cationic } \\
\text { peptide fraction }\end{array}$ & 0.4 & \begin{tabular}{|l|} 
QGR \\
RW \\
SVR \\
GQMRQPI \\
QQQG \\
ASVRT \\
DYLRSC \\
ARDLPGQ \\
RDLPG \\
RGLERA \\
TCRGLERA \\
\end{tabular} & & $\begin{array}{l}200 \mathrm{mg} / \mathrm{kg} \\
\text { hydrolysate, } \\
\text { oral, SHR }\end{array}$ & $\begin{array}{l}-17.9 \text { after } \\
2 \mathrm{~h}\end{array}$ & {$[44]$} \\
\hline $\begin{array}{l}\text { Flaxseed } \\
\text { protein }\end{array}$ & $\begin{array}{l}\text { Gastrointestinal } \\
\text { digest in vitro, } \\
<1 \mathrm{kDa} \\
\text { permeate } \\
\text { fraction }\end{array}$ & 0.040 & $\begin{array}{l}\text { WNI/LNA } \\
\text { NI/LDTDI/L }\end{array}$ & & & & {$[127]$} \\
\hline
\end{tabular}




\begin{tabular}{|c|c|c|c|c|c|c|c|}
\hline \multirow{2}{*}{\begin{tabular}{|l|} 
Source \\
protein
\end{tabular}} & \multirow{2}{*}{$\begin{array}{l}\text { Enzyme or } \\
\text { other process } \\
\text { conditions }\end{array}$} & \multirow{2}{*}{\begin{tabular}{|l}
$\begin{array}{l}\text { ACE } \\
\text { inhibition }\end{array}$ \\
$\begin{array}{l}\mathrm{IC}_{50} \\
(\mathrm{mg} / \mathrm{ml})\end{array}$ \\
\end{tabular}} & \multicolumn{2}{|c|}{ Identified peptides } & \multicolumn{2}{|c|}{ In vivo response } & \multirow[t]{2}{*}{ Ref } \\
\hline & & & Sequences & \begin{tabular}{|l|}
$\begin{array}{l}\text { IC } \\
50 \text { value } \\
(\mu \mathrm{M})\end{array}$ \\
\end{tabular} & \begin{tabular}{|l|} 
Dose \\
administratio \\
n model \\
\end{tabular} & \begin{tabular}{|l|} 
Response $(\Delta$ \\
SBP \\
mmHg)
\end{tabular} & \\
\hline $\begin{array}{l}\text { Sunflower } \\
\text { protein }\end{array}$ & \begin{tabular}{|l|} 
Alcalase \\
Peptide fraction \\
from affinity \\
purification
\end{tabular} & $\begin{array}{l}0.062 \\
1.18 \times 10^{-3}\end{array}$ & & & & & [61] \\
\hline Pea protein & $\begin{array}{l}\text { Gastrointestinal } \\
\text { digest in vitro }\end{array}$ & 0.070 & & & $\begin{array}{l}50 \mathrm{mg} / \mathrm{kg} \\
\text { intravenous, } \\
\text { SHR }\end{array}$ & \begin{tabular}{|l|}
-44, transient \\
and sharp \\
reduction
\end{tabular} & [144] \\
\hline $\begin{array}{l}\text { Pea protein } \\
\text { isolate }\end{array}$ & $\begin{array}{l}\text { Thermolysin, } \\
\text { 3kDa MWCO } \\
\text { permeate }\end{array}$ & ND & & & \begin{tabular}{|l|}
$200 \mathrm{mg} / \mathrm{kg}$ \\
oral, SHR \\
$25-30 \mathrm{~g} /$ day \\
oral, \\
Han:SPDR-cy \\
rat \\
$3 \mathrm{~g} /$ day \\
oral, Human, \\
consumption
\end{tabular} & $\begin{array}{l}-19 \text { after } 4 \mathrm{~h} \\
-30 \text { at weeks } \\
7 \text { and } 8 \\
-6 \text { after } 3 \\
\text { weeks }\end{array}$ & [143] \\
\hline $\begin{array}{l}\text { Chick pea } \\
\text { protein }\end{array}$ & Alcalase & & $\begin{array}{l}\text { Peptide } \\
\text { fractions }\end{array}$ & $\begin{array}{l}0.103- \\
0.117 \\
\mathrm{mg} / \mathrm{ml}\end{array}$ & & & {$[41]$} \\
\hline $\begin{array}{l}\text { Chick pea } \\
\text { legumin }\end{array}$ & Alcalase & & \begin{tabular}{|l|}
$\begin{array}{l}\text { Peptide } \\
\text { peaks }\end{array}$ \\
\end{tabular} & \begin{tabular}{|l|}
$0.011-0.021$ \\
$\mathrm{mg} / \mathrm{ml}$
\end{tabular} & & & {$[43]$} \\
\hline $\begin{array}{l}\text { Common } \\
\text { beans } \\
\text { Pinto beans } \\
\text { Green } \\
\text { lentils } \\
\end{array}$ & $\begin{array}{l}\text { Heat treatment } \\
\text { and in vitro } \\
\text { gastro-intestinal } \\
\text { digestion }\end{array}$ & $\begin{array}{l}0.78-0.83 \\
0.15-0.69 \\
0.008-0.89\end{array}$ & & & & & [131] \\
\hline $\begin{array}{l}\text { Red and } \\
\text { green lentil } \\
\text { protein } \\
\end{array}$ & $\begin{array}{l}\text { In vitro gastro- } \\
\text { intestinal } \\
\text { digestion } \\
\end{array}$ & $0.053-0.190$ & & & & & {$[64]$} \\
\hline $\begin{array}{l}\text { Mung bean } \\
\text { protein }\end{array}$ & $\begin{array}{l}\text { Alcalase, } 6 \mathrm{kDa} \\
\text { MWCO } \\
\text { permeate }\end{array}$ & 0.64 & \begin{tabular}{|l|} 
KDYRL \\
VTPALR \\
KLPAGTLF \\
\end{tabular} & $\begin{array}{l}26.5 \\
82.4 \\
13.4 \\
\end{array}$ & $\begin{array}{l}600 \mathrm{mg} / \mathrm{kg} \\
\text { oral, SHR }\end{array}$ & $\begin{array}{l}-30.8 \text { after } \\
6 \mathrm{~h}\end{array}$ & [48] \\
\hline $\begin{array}{l}\text { Mung bean } \\
\text { sprout }\end{array}$ & $\begin{array}{l}\text { Raw sprout } \\
\text { extract } \\
\text { Dried sprout } \\
\text { extract } \\
\text { Pepsin, trypsin } \\
\text { and } \\
\text { chymotrypsin }\end{array}$ & & & & $\begin{array}{l}600 \mathrm{mg} / \mathrm{kg} \\
\text { intragastric, } \\
\text { SHR }\end{array}$ & $\begin{array}{l}-41 \text { after } 6 h \\
-24 \text { after } 3 h \\
-29 \text { after } 3 h\end{array}$ & [142] \\
\hline Soy protein & Alcalase & 0.065 & \begin{tabular}{|l} 
DLP \\
DG
\end{tabular} & \begin{tabular}{|l|}
4.8 \\
12.3 \\
\end{tabular} & & & [39] \\
\hline
\end{tabular}




\begin{tabular}{|c|c|c|c|c|c|c|c|}
\hline \multirow{2}{*}{\begin{tabular}{|l|} 
Source \\
protein
\end{tabular}} & \multirow{2}{*}{\begin{tabular}{|l|}
$\begin{array}{l}\text { Enzyme or } \\
\text { other process } \\
\text { conditions }\end{array}$ \\
\end{tabular}} & \multirow{2}{*}{\begin{tabular}{|l}
$\begin{array}{l}\text { ACE } \\
\text { inhibition }\end{array}$ \\
$\begin{array}{l}\mathrm{IC}_{50} \\
(\mathrm{mg} / \mathrm{ml})\end{array}$
\end{tabular}} & \multicolumn{2}{|c|}{ Identified peptides } & \multicolumn{2}{|c|}{ In vivo response } & \multirow[t]{2}{*}{ Ref } \\
\hline & & & Sequences & $\begin{array}{l}\text { IC } 50 \text { value } \\
(\mu \mathrm{M})\end{array}$ & \begin{tabular}{|l|} 
Dose \\
administratio \\
n model
\end{tabular} & \begin{tabular}{|l|} 
Response $(\Delta$ \\
SBP \\
mmHg)
\end{tabular} & \\
\hline Soybean & Fermentation & 0.45 & $\begin{array}{l}\text { AW } \\
\text { GW } \\
\text { AY } \\
\text { SY } \\
\text { GY } \\
\text { AF } \\
\text { VP } \\
\text { AI } \\
\text { VG } \\
\end{array}$ & \begin{tabular}{|l}
$\mu \mathrm{g} / \mathrm{ml}$ \\
0.03 \\
0.05 \\
0.07 \\
0.10 \\
0.19 \\
0.48 \\
0.69 \\
1.1 \\
\end{tabular} & $\begin{array}{l}\text { Diet contained } \\
10 \% \mathrm{v} / \mathrm{w} \text { of } \\
\text { fermented soy } \\
\text { product } \\
\text { oral, SHR }\end{array}$ & \begin{tabular}{|l|} 
\\
week
\end{tabular} & [184] \\
\hline Rye & \begin{tabular}{|l|} 
Sourdough \\
Lactobacillus \\
reuteri TMW \\
1.106 and added \\
protease
\end{tabular} & & $\begin{array}{l}\text { VPP } \\
\text { IPP } \\
\text { LQP } \\
\text { LLP }\end{array}$ & $\mid \begin{array}{l}9 \\
5 \\
2 \\
57\end{array}$ & & & [149] \\
\hline Rice & Alcalase & 0.14 & TQVY & 18.2 & \begin{tabular}{|l}
$600 \mathrm{mg} / \mathrm{kg}$ \\
hydrolysate \\
$30 \mathrm{mg}$ \\
peptide/kg \\
SHR, oral \\
\end{tabular} & \begin{tabular}{|l}
-25.6 after \\
$6 \mathrm{~h}$ \\
-40 after $6 \mathrm{~h}$
\end{tabular} & {$[153]$} \\
\hline $\begin{array}{l}\text { Maize, } \alpha- \\
\text { zein }\end{array}$ & Thermolysin & & $\begin{array}{l}\text { LRP } \\
\text { LSP } \\
\text { LQP }\end{array}$ & $\begin{array}{l}0.29 \\
1.7 \\
2.0\end{array}$ & \begin{tabular}{|l|} 
Peptide (LRP) \\
$30 \mathrm{mg} / \mathrm{kg}$ \\
$\mathrm{SHR}$ \\
intravenous \\
\end{tabular} & $\begin{array}{l}-152 \mathrm{~min} \\
\text { after } \\
\text { injection }\end{array}$ & {$[31]$} \\
\hline Wheat bran & Autolysis & 0.08 & $\begin{array}{l}\text { LQP } \\
\text { IQP } \\
\text { LRP } \\
\text { VY } \\
\text { IY } \\
\text { TF }\end{array}$ & $\begin{array}{l}\text { peptide- } \\
\text { fraction } \\
0.14 \\
\mathrm{mg} / \mathrm{ml}\end{array}$ & \begin{tabular}{|l|}
$10 \mathrm{mg} / \mathrm{ml}$ \\
oral, SHR
\end{tabular} & -45 after $2 \mathrm{~h}$ & $\begin{array}{l}{[185]} \\
{[186]}\end{array}$ \\
\hline
\end{tabular}

Table 1. ACE-inhibitory activities in vitro and antihypertensive effect in vivo of plant protein-derived hydrolysates and peptides

autolysis of protein isolates from the potato tuber tissue enhances ACE-inhibition which may be due to the native proteolytic activity of potato tuber proteins.

Peña-Ramos and Xiong [51] used different enzymes to produce hydrolysates from native and heated soy protein isolates. They reported that using different enzymes resulted in the formation of a mixture of peptides with different degrees of hydrolysis and accordingly different ranges of antioxidant activity. It has been found that antioxidant activity of Alcalase derived hydrolysates is higher than that of other hydrolysates [52-54]. It is also 
reported that peptides produced by Alcalase have diverse biological activities, including antioxidant activity [55]. In comparison to other proteases, it provided higher yields of antioxidative peptides and develops shorter peptides. Udenigwe and colleagues [55] observed that release of radical scavenging peptides depends on the specificity of protease used in hydrolysis. In another study, flaxseed protein was treated with thermolysin followed by pronase to produce antioxidant peptides [42]. Moreover, pepsin, pancreatin, neutrase and esperase have been used to produce antioxidative hydrolysates and peptides $[13,42,51,56,57]$.

Simulated gastrointestinal enzymatic process has also been used to mimic normal human digestion of proteins to evaluate the possibility of releasing potent bioactive peptides after normal consumption of food proteins. The combination of pepsin-trypsin-chymotrypsin or pepsin-pancreatin has been used to simulate the gastrointestinal degradation of proteins in humans [58]. Pepsin treatment alone cannot effectively elicit ACE-inhibitory peptides from buckwheat protein, while this enzyme followed by chymotrypsin and trypsin lead to a significant increase in ACE-inhibitory activity [59]. In some studies, plant protein hydrolysates generated during pepsin digestion have potent ACE-inhibitory peptides. Lower ACE-inhibitory activity was found after subsequent digestion with pancreatin, suggesting that the active components were hydrolyzed [60,61]. For the pea proteins, high ACE-inhibitory activity is reached at the early stage of pepsin hydrolysis and the level is maintained during the small intestine phase using trypsin-chymotrypsin treatment [62]. While digestion of red lentils with trypsin showed moderate ACE inhibition (IC50 value of $0.44 \mathrm{mg} / \mathrm{ml}$ ), addition of pepsin and chymotrypsin clearly improved it (IC50 of $0.09 \mathrm{mg} / \mathrm{ml}$ ) $[63,64]$.

Careful choice of suitable enzymes and digestion conditions such as optimal temperature, degree of hydrolysis and enzyme-substrate ratio, as well as the control of hydrolysis time, are crucial for obtaining protein hydrolysates with desirable functional and bioactive properties. Hydrolysis can be performed by conventional batch hydrolysis or by continuous hydrolysis using ultrafiltration membranes. The traditional batch method has several disadvantages, such as the relatively high cost of the enzymes and their inefficiency compared to a continuous process, as noted in numerous studies $[65,66]$. The hydrolysis process is feasible to scale-up production of peptides from laboratory scale to pilot and industrial plant scales with conserved peptide profiles and bioactivity of the resulting products [67]. The crude protein hydrolysate may be further processed, for example by passage through ultrafiltration membranes, in order to obtain a more uniform product with the desired range of molecular mass [68]. Alcalase hydrolysate from soy isolate was ultrafiltrated with 1-30 kDa membranes and ACE-inhibitory activities were analysed. The IC50-values for $1 \mathrm{kDa}$ and $10 \mathrm{kDa}$ permeates were almost the same, 0.080 and $0.078 \mathrm{mg} / \mathrm{ml}$, respectively, but recovery yield of $10 \mathrm{kDa}$ permeate was much higher than that of $1 \mathrm{kDa}$ permeate [69]. Ultrafiltration membrane reactors have been shown to improve the efficiency of enzyme-catalysed bioconversion, to increase product yields, and to be easily scaled up. Furthermore, ultrafiltration membrane reactors yield a consistently uniform product with desired molecular mass characteristics $[65,68]$. Low molecular mass cut-off membranes are useful for concentrating bioactive peptides from the higher molecular mass components 
remaining, including undigested polypeptide chains and enzymes. Other techniques such as nanofiltration, ion-exchange membranes, or column chromatographic methods can be used in further concentration and purification of the peptides [70].

A number of studies have shown that antihypertensive peptides are liberated during fermentation of milk. Fermented milk products prepared using different strains of lactic acid bacteria have been found to exert antihypertensive and antioxidative activities [71, 72]. Moreover, several antioxidative and ACE-inhibitory peptide sequences have been identified from fermented milk [73]. Only few experimental investigations to produce these compounds by fermentation of plant proteins have been reported. Fermentation of rapeseed and flaxseed proteins with Lactobacillus helveticus and Bacillus subtilis yields to products containing compounds with ACE-inhibitory and inhibition of lipid peroxidation capacities [74]. Fermented soybean products such as natto, tempeh, and douche also contain antioxidative and ACE-inhibitory peptides due to the action of fungal proteases. The results have indicated that the processing techniques have an impact on the ACE-inhibitory activities of soy products. Different fermented soybean foods showed IC 50 values of 0.51 $\mathrm{mg} / \mathrm{ml}$ for tempeh, $1.77 \mathrm{mg} / \mathrm{ml}$ for tofuyo, 3.44 and $0.71-17.80 \mathrm{mg} / \mathrm{ml}$ for soy sauce, 5.35 and $1.27 \mathrm{mg} / \mathrm{ml}$ for miso paste, and $0.16,0.19$ and $0.27 \mathrm{mg} / \mathrm{ml}$ for natto [24,75, 76]. Commercial Chinese style soy paste exhibited ACE-inhibitory activities with the lowest and the highest IC 50 values of 0.012 and $3.241 \mathrm{mg} / \mathrm{ml}$, respectively [77]. Tsai and colleagues [78] fermented soy milk with lactic acid bacteria (Lb. casei, Lb., acidophilus, Lb. bulcaricus, Streptococcus thermophilus and Bifidobacterium longum) and IC50-value was $2.89 \mathrm{mg} / \mathrm{ml}$ after $30 \mathrm{~h}$ fermentation. When a protease (Prozyme 6) was added after $5 \mathrm{~h}$ fermentation, much lower IC 50 -value $(0.66 \mathrm{mg} / \mathrm{ml})$ was obtained. Natto has shown to have radical scavenging activity and inhibitory effect on the oxidation of rat plasma LDL in vitro [79]. The aqueous extracts of Douchi showed radical scavenging activities and chelating ability of ferrous ions. The radical scavenging activities were higher than that of Trolox, an analogue of vitamin E used as a standard [80].

\subsection{Structure-activity relationship}

ACE-inhibitory peptides are generally short sequences often carrying polar amino acid residues like Pro. This is in agreement with the results of Natesh and co-workers [81] who showed that the active site of ACE cannot accommodate large peptide molecules. The Cterminal tripeptide strongly influences the binding of substrate or a competitive inhibitor to ACE. Many ACE-inhibitory peptides identified from different food sources, structureactivity studies indicated that C-terminal tripeptide residues play a predominant role in competitive binding to the active site of ACE. It has been reported that this enzyme prefers substrates or inhibitors containing hydrophobic (aromatic or branched side chains) amino acid residues at each of the three C-terminal positions. The most effective ACE-inhibitory peptides identified contain Tyr, Phe, Trp, and/or Pro at the C-terminal. In addition, structure-activity data suggests that the positive charge of Lys ( $\varepsilon$-amino group) and Arg (guanidine group) as the C-terminal residue may contribute to the inhibitory potency [8284]. Quantitative structure-activity relationship (QSAR) modelling was used to develop 
statistical computer models potentially capable of identifying ACE-inhibitory peptides based on structure-activity data [85]. A relationship was found between hydrophobicity and positively charged amino acid in C-terminal position, size of amino acid next to C-terminal position and ACE inhibition of peptides up to six amino acids in length. Moreover, no relationship between $\mathrm{N}$-terminal structure and inhibition activity was found.

The exact mechanism underlying the antioxidant activity of peptides has not fully been understood, as various studies have displayed that they are inhibitors of lipid peroxidation, scavengers of free radicals and chelators of transition metal ions [86, 87]. In addition, it has been reported that antioxidative peptides keep cells safe from damage by ROS through the induction of genes [88]. Antioxidative properties of the peptides are more related to their composition, structure, and hydrophobicity. Tyr, Trp, Met, Lys, Cys, and His are examples of amino acids that cause antioxidant activity. Amino acids with aromatic residues can donate protons to electron deficient radicals. This property improves the radical scavenging properties of the amino acid residues $[89,90]$. It is proposed that the antioxidative activity of His containing peptides is in relation with the hydrogen donating, lipid peroxyl radical trapping and/or the metal ion chelating ability of the imidazole group [87, 91]. On the other hand, $\mathrm{SH}$ group in Cys has an independently crucial antioxidant action due to its direct interaction with radicals [92]. In addition to the amino acid composition, their correct position in peptide sequence plays an important role in antioxidative properties of peptides. Chen and colleagues [93] designed 28 synthetic peptides following the structure of an antioxidative peptide (Leu-Leu-Pro-His-His) from digestion of soybean protein conglycinin. According to the results, Pro-His-His sequence displayed the greatest antioxidative activity among all tested peptides. The antioxidant activity of a peptide was more dependent on His-His segment in the Leu-Leu-Pro-His-His-domain and its activity was decreased by removing a His residue from the C-terminus. Moreover, substitution of L-His by D-His in a peptide leads reduction of activity [93]. They concluded that the correct position of imidazole group is the key factor influencing the antioxidant activity. Saito and co-workers [94] also studied antioxidative activity of peptides created in two tripeptide libraries. According to their results, for the 114 peptides containing either His or Tyr residues, tripeptides containing two Tyr residues showed higher activity in the linoleic acid peroxidation system than tripeptides containing two His residues. Further, Tyr-His-Tyr showed strong synergistic effects with phenolic antioxidants. It has been shown that certain amino acids can exert higher antioxidative properties when they are incorporated in dipeptides [95] and some peptide bond or its structural conformation can reduce the antioxidant activity of the constituent amino acids [96].

\subsection{In vitro and in vivo activity}

The search for in vitro ACE-inhibitors is the most common strategy followed in the selection of potential antihypertensive peptides derived from food proteins. In vitro ACE-inhibitory activity is generally measured by monitoring the conversion of an appropriate substrate by ACE in the presence and absence of inhibitors. There are several methods, and those based on spectrophotometric [97-99] and high-performance liquid chromatography (HPLC) assays 
are most commonly utilized [100-102]. Hippuryl-His-Leu (HHL) is one of the oldest and most used methods for determining the ACE activity or inhibition [97, 99-101]. The broadly used spectrophotometric method of Cushman and Cheung [97] is based on the hydrolysis of HHL by ACE to hippuric acid and His-Leu, and the extent of hippuric acid released is measured after its extraction with ethyl acetate. The liberated hippuric acid can also be measured by chromatographic assays avoiding the extraction step [102]. The method based on the substrate 2-furanacryloyl-phenylalanylglycyl-glycine (FAPGG) was developed by Holmquist and colleagues [103] and can be applied in microtiter plates [98]. Substrates such as o-aminobenzoylglycyl-p-nitrophenylalanylproline are designed to perform in fluorometric assays [104, 105].

Specific assays have not yet been developed or standardized to measure the antioxidative capacity of peptides or peptide mixtures. Therefore, assays that are commonly used for measuring antioxidative capacity of non-peptidic antioxidants have been used in the literature to measure the antioxidative capacity of peptides as well. Due to the complexity of oxidative processes occurring in food or biological systems as well as the different antioxidative mechanisms by which various compounds may act, finding one method that can characterize the overall antioxidative potential of food is not an easy task. Nevertheless, methods such as the Trolox equivalent antioxidant capacity (TEAC) assay, oxygen radical absorbance capacity (ORAC) assay, and the total radical-trapping antioxidant parameter (TRAP) assay have been widely reported in the literature for measuring antioxidative capacity of food and biological samples [106, 107]. Commonly used assays include measuring the inhibition of lipid peroxidation in a linoleic acid model system and the capacity to scavenge the 2,2'-azino-bis(3-ethylbenzothiazoline-6-sulphonic acid)/2,2Diphenyl-1-picrylhydrazyl (ABTS/DPPH) radicals.

In vitro cultured cell model systems allow for rapid, inexpensive screening of compounds for their bioavailability, metabolism, as well as bioactivity, compared to expensive and timeconsuming animal studies and human clinical trials. Endothelial cells are currently used as in vitro model systems for various physiological and pathological processes, especially in angiogenesis research. Endothelial dysfunction, an initiator of atherosclerosis, is manifested by altered NO and endothelin-1 (ET-1) homeostasis. ET-1 is one of the most potent endogenous vasoconstrictors and impaired $\mathrm{NO}$ release precedes the development of atherosclerosis [108]. NO is produced by the enzyme endothelial NO synthase (eNOS) which converts L-Arg in the presence of $\mathrm{O}_{2}$ and NADPH into L-citruline and NO. There are several assays available to analyze NO, ET-1, or expression of eNOS after exposure to compounds of interest. Use of cell culture models for antioxidant research is particularly important since the studies to date have demonstrated that the mechanism of the action of antioxidants in human health promotion go beyond the antioxidant activity of scavenging free radicals [109]. During experiments, intracellular oxidation of cells can be induced by using a peroxy radical generator or by using hydrogen peroxide $\left(\mathrm{H}_{2} \mathrm{O}_{2}\right)$ [110]. The 20,70dichlorofluorescein diacetate (DCFH-DA) probe can be used to measure the extent of intracellular radical formation with and without added antioxidative compound in order to assess the cellular antioxidant activity (CAA) [111]. 
The antihypertensive effects can be assessed by in vivo experiments using spontaneously hypertensive rats (SHR) that constitute an accepted animal model to study human essential hypertension [88]. A great number of studies have addressed the effects of both short-term and long-term administration of potential antihypertensive milk protein-derived peptides using this animal model [88, 112]. In vitro measurements of antioxidant capacity of compounds in interest cannot be directly related to their capacity in vivo. Biomarkers of lipid and protein peroxides as well as DNA damage can be assessed to monitor changes in oxidative stress in vivo. Only few studies so far have been done on plant derived peptides in animal models or human clinical trials.

\subsection{ACE-inhibitory and antioxidant peptides}

\subsubsection{Potato and other root crops}

During the last decade the in vitro capacity of tuber protein -derived peptides to inhibit ACE have gained increasing interest (Table 1). Hsu and colleagues [113] reported that yam (Dioscorea alata) tuber dioscorin possess high ACE-inhibitory capacity and the digestion with pepsin increased the efficacy further. Moderate ACE-inhibition in vitro has been reported for purified yam (Dioscorea batatas) tuber mucilage [114] and for an enzymatic digest as well as for an autolysate of yam (Dioscorea opposita) tuber extract $[115,116]$. However, the potential impact of other compounds, such as phenolic compounds and sugars, on the observed ACE inhibition should be taken into consideration. It has been shown that naturally occurring phenolic compounds, such as flavonoids and proanthocyanidins, have inhibition activity towards ACE [117].

Sweet potato proteins defensin and thioredoxin h2 which were overproduced in Esherichia coli showed moderate ACE-inhibitory capacity (IC50 of 0.190 and $0.152 \mathrm{mg} / \mathrm{ml}$, respectively) and both proteins showed mixed type inhibitor against ACE using FAPGG as substrate. Hydrolysis with trypsin increased the capacity. Several peptides contained in the hydrolysate with $\mathrm{IC}_{50}$ values from 1.31 to $265.43 \mu \mathrm{M}$ were analyzed [118, 119]. Trypsin inhibitor from the root storage protein of sweet potato, inhibited ACE in a dose-dependent manner $(50-200 \mu \mathrm{g} / \mathrm{ml}$, with $31.9-53.2 \%$ inhibition), and the IC50 value was $187.96 \mu \mathrm{g} / \mathrm{ml}$. After digestion with pepsin the ACE-inhibition increased and peptides were designed by simulating the pepsin cutting sites of sporamin A. Finally, ten new ACE-inhibitory peptides showed IC50-values from 2.3 to $849.7 \mu \mathrm{M}$ [120]. Sweet potato protein isolate digested with 16 different proteases showed variability in digestibility from 44.7 to $97.3 \%$ and IC50 values from 0.16 to $1.08 \mathrm{mg} / \mathrm{ml}$. Based on these results four most potent enzymes (Thermoase PC 10F, Protease S, Proleather FG-F and Orientase 22BF) were selected and combined effect of enzymes were tested. Combination of Thermoase PC 10F, Protease S and Proleather FG-F produced potent ACE-inhibition ( $\mathrm{IC}_{50}$ of $0.137 \mathrm{mg} / \mathrm{ml}$ ). Finally, four different peptides derived from sweet potato storage protein, sporamin, were identified with IC 50 values from 9.5 to $300.4 \mu \mathrm{M}$ [121]. The lowest IC 50 values were obtained for synthetic tripeptides, Ile-ThrPro $(9.5 \mu \mathrm{M})$, Gly-Gln-Tyr $(52.3 \mu \mathrm{M})$ and Ile-Ile-Pro $(80.8 \mu \mathrm{M})$. 
The protein-rich by-product fraction from potato (Solanum tuberosum) starch industry, potato tuber liquid, has been found to be a valuable source of ACE-inhibitory peptides [13]. The ACE-inhibitory activity of potato tuber liquid was moderate and enzymatic digestion was needed to enhance the activity to high level. Alcalase digest showed the highest ACEinhibitory activity and the digest was chromatographically separated to highly active peptide fractions. The potato liquid Alcalase hydrolysate produced the highest radical scavenging potency even though no statistically significant differences were found among hydrolysates produced by Alcalase, Neutrase and Esperase. Mäkinen and colleagues [47] reported that autolysis of protein isolates from the potato tuber tissue enhances ACE inhibition which may be due to the native proteolytic activity of potato tuber proteins. The results indicated a relevant role of potato tuber storage proteins in the production of ACEinhibitory peptides during the autolysis. Enrichment of recombinant potato tuber protein to the autolysis enhanced the production of activity significantly, which suggests possibility to enhance potato tuber ACE-inhibitory potential by means of biotechnological tools. Anyhow, more research is needed to characterize and identify the ACE-inhibitory potato peptides and to evaluate the in vivo antihypertensive potential.

Recently, antihypertensive effects of some tuber plant -derived protein digests have been evaluated in vivo using SHR animal model, although no tuber protein -derived peptides in pure form have been reported. The proteins tested in the in vivo trials have concerned the antihypertensive effects of the main storage proteins of the tubers and peptides derived from these proteins. Among the tuber proteins, the in vivo antihypertensive effects of yam (Dioscorea alata) tuber proteins are the most studied. Lin and co-workers [122] purified storage proteins, dioscorins from yam tubers, that were digested with pepsin and evaluated for their antihypertensive effects in SHR. The maximum effect after single oral administration was observed after $4 \mathrm{~h}$ with the dioscorin isolate and after $8 \mathrm{~h}$ with the peptic hydrolysate, while the antihypertensive effect of the peptic digest was more pronounced ($33.7 \mathrm{mmHg}$ Mean arterial pressure, MAP) and less transient than that of the dioscorin isolate $(-21.5 \mathrm{mmHg} \mathrm{MAP})$. The long-term antihypertensive effect of the dioscorin isolate was tested for 25 days with daily oral administration and the greatest reductions in systolic blood pressure (SBP) and diastolic blood pressure (DBP) were observed on the ninth day. Liu and co-workers [123] tested the antihypertensive effects of different yam tuber products on SHR. The yam tuber alcohol-insoluble solids and water extract before and after heat treatment were observed to decrease the blood pressure after single oral administration. The most pronounced effect with the lowest dose was found with the alcohol-insoluble-solids product, which contained the yam tuber dioscorins. Iwai and Matsue [124] reported moderate antihypertensive effects of an edible tuber Apios Americana Medikus in SHR. The animals ingested water extract of the tubers that was rich in Pro. The antihypertensive effect was suggested to be due to Pro-rich peptides, which were released during digestion. Sweet potato protein digest made with combination of three proteases (Thermoase PC10F, Protease S and Proleather FG-F) showed a dose dependent decrease in SBP after single oral administration in SHR [121]. 


\subsubsection{Oil seed plants-derived peptides}

According to the published data, enzymatic hydrolysis is required to release antihypertensive peptides from oil seed plant proteins. Only few peptide sequences have been identified from oil seed plants. Four ACE-inhibitory peptides were isolated from the rapeseed subtilisin digest of which Ile-Tyr and Arg-Ile-Tyr can be found in the primary structure of napin and Val-Trp and Val-Trp-Ile-Ser exist in the primary structure of cruciferin and ribosomal protein, respectively. Among the peptides isolated, Ile-Tyr and Val-Trp can be considered true ACE-inhibitors because IC 50 values for these peptides before and after pre-incubation with ACE were found to be the same. Val-Trp-Ile-Ser is a pro-drug type ACE-inhibitor, as pre-incubation with ACE of Val-Trp-Ile-Ser intensified inhibitory activity of this peptide [125]. In addition, to these rapeseed peptides, two peptide sequences with high ACE-inhibitory capacity were identified from canola meal hydrolysed with Alcalase, Val-Ser-Val and Phe-Leu, located in the primary structure of canola napin and cruciferin proteins [46]. Low-molecular weight cationic peptide fractions from flaxseed protein hydrolysed by Alcalase or thermolysin showed concentration dependent ACEinhibition (IC50 0.0275-0.151 mg/ml) [126]. The Alcalase cationic peptide and thermolysin hydrolysate showed mixed type inhibition of ACE activity. Several peptides were detected in a cationic peptide fraction of a trypsin \& Pronase digest of flaxseed, which showed moderate ACE inhibition in vitro and antihypertensive effects in SHR [44]. A pentapeptide Trp-Asn-Ile-Leu-Asn-Ile-Leu and a hexapeptide Asn-Ile-Leu-Asp-Thr-Asp-Ile-Leu were identified from flaxseed protein digested with an in vitro digestion model [127]. Anyhow, ACE-inhibitory activity of these flaxseed derived peptides has not been evaluated individually and thus, the ACE-inhibitory capacity of these peptides in a pure form is not clear [44, 126, 127].

Despite the high in vitro ACE-inhibitory potency of Alcalase digests of oil seed proteins, their antihypertensive effects in vivo have not been evaluated yet. Subtilisin digest of rapeseed and tryptic digest of flaxseed have shown antihypertensive properties in SHR. Marczak and co-workers [125] studied the Subtilisin and pepsin digests of rapeseed in SHR. Subtilisin digest of rapeseed protein showed dose dependent antihypertensive effect after oral administration to SHR and its effect was significant even at a single dose of $0.15 \mathrm{~g} / \mathrm{kg}$. The Subtilisin digest was subjected to hydrolysis with different proteases to simulate gastrointestinal digestion in vitro and the ACE-inhibitory activity was changed only slightly indicating that ACE-inhibitory peptides present in the Subtilisin digest are relatively resistant. The antihypertensive activities of Val-Trp, Val-Trp-Ile-Ser, Ile-Tyr and Arg-Ile-Tyr were tested following oral administration to SHR. The maximum hypotensive activity of Val-Trp, Val-Trp-Ile-Ser and Ile-Tyr occurred $2 \mathrm{~h}$ after administration, whereas Arg-Ile-Tyr (rapakinin) had the maximum effect $4 \mathrm{~h}$ after administration. All peptides displayed dosedependent antihypertensive effect. Hypotensive activity of the peptides was compared after oral administration to young (19-20 weeks) and old (28-30 weeks) SHR. Usually the hypotensive effect of ACE inhibitors in old SHR is lower than in young SHR. The hypotensive effects of Val-Trp, Val-Trp-Ile-Ser and Ile-Tyr were lower in old rats, but in the case of rapakinin the effect was similar in old and young rats. The authors suggested that 
another mechanism besides ACE inhibition may be involved in hypotensive effect of rapakinin. Recently, the hypotensive effect of rapakinin was found to be mediated mainly by the prostaglandin IP (PGI2-IP) receptor followed by CCK1 receptor-dependent vasorelaxation [128]. In addition to hypotensive effects, the napin-derived peptide rapakinin has been reported to possess multifunctional properties. Rapakinin dose-dependently decreased food intake and gastric emptying after oral administration at a dose of $150 \mathrm{mg} / \mathrm{kg}$ in mice [129] and recently, Yamada and colleagues [130] reported anti-opioid activity related to the hypotensive effects for rapakinin.

Peptide fraction from the enzymatic digest of flaxseed protein was recently reported to possess hypotensive activity in SHR [44]. An Arg-rich peptide fraction was produced from flaxseed protein using trypsin and pronase and by subsequent concentration with combined electrodialysis and ultrafiltration. The hypotensive effect of the flaxseed derived Arg-rich peptide fraction was tested on SHR and the effects were compared to the effects of inherent flaxseed protein isolate and amino acid form of Arg. The maximum hypotensive effect of the cationic peptide fraction was observed already $2 \mathrm{~h}$ after oral administration while the amino acid form of Arg showed lower hypotensive activity, $-10.3 \mathrm{mmHg}$. On the other hand, the flaxseed protein isolate exhibited a slow-acting hypotensive effect with maximum of -18.4 $\mathrm{mmHg}(\mathrm{SBP})$ at $6 \mathrm{~h}$ after the administration. The hypotensive effect of the Arg-rich peptide fraction was longer-lasting when compared to the free amino acid form of Arg and the authors suggested that this might be related to more efficient absorption of peptides and the ability of peptides to translocate directly into the cells, obviating the need for transporters. The observed hypotensive activity of flaxseed protein and peptide fraction could be due to vasodilatory activity of NO synthesized from the Arg through the L-Arg-NO pathway in the vascular endothelium, or ACE- and renin-inhibition observed in vitro by the cationic peptide fraction.

\subsubsection{Legume derived peptides}

Several enzymes have been used to produce pulse protein hydrolysates having bioactive properties. It has been suggested that hydrolysates of chickpea legume and mung bean obtained by Alcalase treatments are good sources of ACE-inhibitory peptides [43, 48]. Potential ACE-inhibitory potencies of common dry beans, dry pinto beans and green lentils increased during in vitro gastrointestinal digestion have been reported, with IC $_{50}$ values of $0.78-0.83,0.15-0.69$ and $0.008-0.89 \mathrm{mg}$ protein/ml, respectively [131]. In addition, $15 \mathrm{~min}$ heat treatment effectively increased the ACE-inhibitory activity of the stomach digest [43, 131]. Digestion simulating the physiological conditions of pea proteins sufficed to achieve the highest ACE-inhibitory activity with $\mathrm{IC}_{50}$ value of $0.076 \mathrm{mg} / \mathrm{ml}$ [132]. Furthermore, it has been suggested that red lentil protein hydrolysates have ACE-inhibitory properties. The ACE-inhibitory property of the tryptic hydrolysates varied as a function of the protein fraction with the total lentil protein hydrolysate having the lowest IC $50(0.440 \pm 0.004 \mathrm{mg} / \mathrm{ml})$. This indicates that lentil varieties having higher amounts of legumin and albumin proteins may have higher ACE-inhibitory properties [63]. Pedroche and co-workers [41] hydrolysed chickpea protein isolate with Alcalase to produce a bioactive hydrolysate having ACE- 
inhibitory properties with an IC 50 value of $0.190 \mathrm{mg} / \mathrm{ml}$. Four peptide-fractions with average molecular weight of $900 \mathrm{Da}$, representing peptides with six to eight amino acid residues were isolated. The IC 50 values were $0.103-0.117 \mathrm{mg} / \mathrm{ml}$ and two of the peptides showed competitive and two showed uncompetitive mechanism [41]. In addition, six ACEinhibitory peptides with IC 50 values ranging from 0.011 to $0.012 \mathrm{mg} / \mathrm{ml}$ have been isolated from chickpea hydrolysed by Alcalase. All these peptides contained Met and were rich in other hydrophobic amino acids [43]. Two lentil varieties were hydrolysed with different enzymes and $\mathrm{IC}_{50}$ values ranged between 0.053 and $0.190 \mathrm{mg} / \mathrm{ml}$. Furthermore, the inhibition mechanism investigated using Lineweaver-Burk plots revealed a non-competitive inhibition of ACE with inhibitor constants (Ki) between 0.16 and $0.46 \mathrm{mg} / \mathrm{ml}$ [40]. Three dipeptides, Ile-Arg, Lys-Phe and Glu-Phe were isolated and identified from Alcalase hydrolysate of pea protein isolate. The peptides showed strong inhibitions ( $\mathrm{IC}_{50}$ values $<25$ $\mathrm{mM}$ ) of ACE and renin [133].

Enzymatic hydrolysate of soy protein showed a moderate ACE-inhibitory activity $(0.034$ $\mathrm{mg} / \mathrm{ml}$ ) [39] as compared with values reported ranging from 0.021 to $1.73 \mathrm{mg} / \mathrm{ml}[5,6,49$, 70]. Lo and co-workers [134] applied the dynamic model for the in vitro digestion of isolated soy proteins. They concluded that ACE-inhibitory activity was dependent on the digestion time and the heat treatment of soy protein. Pepsin hydrolysis of isolated soy protein produced peptides with a higher ACE-inhibitory activity due to the increased digestion time. Hydrolysis by pancreatin produced soy peptides with higher ACE-inhibitory activity as compared to pepsin hydrolysates, but decresed inhibitory activity appeared after longer digestion time. These results suggest that at the longer digestion time pancreatin may have hydrolysed the peptides from pepsin digestion that had strong ACE-inhibitory activity, and then turned them into peptides with lower ACE-inhibitory activity.

Pea protein hydrolysates by thermolysin contained low molecular weight $(<3 \mathrm{kDa})$ peptides with various antioxidant activities that were dependent on the amounts of hydrophobic and aromatic amino acid constituents [135] (Table 2). Peptide fractions with the least cationic property had significantly stronger scavenging activity against DPPH and $\mathrm{H}_{2} \mathrm{O}_{2}$. Generally, the scavenging of $\mathrm{O}_{2}{ }^{-}-$and $\mathrm{H}_{2} \mathrm{O}_{2}$ was negatively related with the cationic property of the peptide fractions [136]. Chick pea hydrolysate with antioxidant activities was prepared from chickpea protein isolates by Alcalase. This hydrolysate was separated with Sephadex G-25. Four fractions were obtained, and fraction IV had the highest antioxidant activities assayed by free radical scavenging effects [137]. The active peptide was identified as Asn-Arg-TyrHis-Glu. This peptide quenched the free radical sources DPPH, hydroxyl, and superoxide free radicals. Furthermore, the inhibition of the peptide on lipid peroxidation was greater than that of $\alpha$-tocopherol [57].

Different hydrolysis conditions of soy protein isolates have resulted in peptide mixtures with different antioxidant properties. Native and heated soy protein isolate hydrolysed with different enzymes resulted in different degree of hydrolysis ranging from 1.7-20.6 with antioxidant activity ranging from $28 \%$ to $65 \%$ [138]. Zhang and coworkers [139] used three microbial proteases to produce hydrolysates with degree of hydrolysis values from $13.4 \%$ to $26.1 \%$ and with different oxygen radical absorbance capacity (ORAC), DPPH-radical 


\begin{tabular}{|c|c|c|c|c|}
\hline $\begin{array}{l}\text { Source of } \\
\text { proteins or } \\
\text { hydrolysates }\end{array}$ & $\begin{array}{l}\text { In vitro methods } \\
\text { used in measuring } \\
\text { antioxidant } \\
\text { capacity }\end{array}$ & $\begin{array}{l}\text { Enzymes or other } \\
\text { process conditions } \\
\text { used }\end{array}$ & $\begin{array}{l}\text { Antioxidative peptides } \\
\text { identified }\end{array}$ & Ref \\
\hline $\begin{array}{l}\text { Potato liquid } \\
\text { fraction }\end{array}$ & $\mathrm{ABTS}^{+-}$scavenging & $\begin{array}{l}\text { Alcalase }^{1}, \\
\text { Esperase, Neutrase }\end{array}$ & Not specified & [13] \\
\hline $\begin{array}{l}\text { Potato protein } \\
\text { concentration }\end{array}$ & $\begin{array}{l}\text { ABTS }^{+-} \text {scavenging } \\
\text { Emulsion oxidative } \\
\text { stability }\end{array}$ & Alcalase & $\begin{array}{l}\text { SSEFTY } \\
\text { IYLGQ }\end{array}$ & [14] \\
\hline Soybean proteins & $\begin{array}{l}\text { Liposome } \\
\text { oxidizing system }\end{array}$ & $\begin{array}{l}\text { Chymotrypsin, } \\
\text { Pepsin, Papain, } \\
\text { Flavourzyme, } \\
\text { Alcalase, Protamex }\end{array}$ & Not specified & [51] \\
\hline $\begin{array}{l}\text { Soybean protein } \\
\text { b-conglycin }\end{array}$ & $\begin{array}{l}\text { Linoleic acid } \\
\text { peroxidation } \\
\text { system }\end{array}$ & $\begin{array}{l}\text { Protease } \mathrm{M}, \\
\text { Protease N, } \\
\text { Protease P, } \\
\text { Protease S }\end{array}$ & $\begin{array}{l}\text { VNPHDHQN } \\
\text { LVNPHDQN } \\
\text { LLPHH } \\
\text { LLPHHADADY } \\
\text { VIPAGYP } \\
\text { LQSGDALRVPSGTTYY }\end{array}$ & [141] \\
\hline $\begin{array}{l}\text { Yellow pea seed } \\
\text { protein }\end{array}$ & $\begin{array}{l}\text { Radical (DPPH, } \mathrm{O}_{2-}^{-} \\
\left.\mathrm{H}_{2} \mathrm{O}_{2}\right) \text { scavenging } \\
\text { and inhibition of } \\
\text { linoleic acid } \\
\text { oxidation }\end{array}$ & Thermolysin & NRYHE & [135] \\
\hline Barley glutelin & $\begin{array}{l}\text { Radical scavenging } \\
\text { capacity }\left(\mathrm{DPPH} / \mathrm{O}_{2}^{-}\right. \\
\left./ \mathrm{OH}^{-}\right), \mathrm{Fe}^{2+-} \\
\text { chelating effect and } \\
\text { reducing power }\end{array}$ & Alcalase & $\begin{array}{l}\text { QKPFPQQPPF } \\
\text { PQIPEEF } \\
\text { LRTLPMSVNVPL }\end{array}$ & [54] \\
\hline Wheat gluten & $\begin{array}{l}\text { Linoleic acid } \\
\text { peroxidation } \\
\text { system }\end{array}$ & Pepsin & $\begin{array}{l}\text { LQPGQGQQG } \\
\text { AQIPQQ }\end{array}$ & [56] \\
\hline $\begin{array}{l}\text { Rice endosperm } \\
\text { protein }\end{array}$ & $\begin{array}{l}\mathrm{O}_{2}, \mathrm{OH} \text { and } \mathrm{DPPH} \\
\text { radical } \\
\text { sacavenging } \\
\text { capacity, Linoleic } \\
\text { acid peroxidation } \\
\text { system }\end{array}$ & $\begin{array}{l}\text { Alcalase, } \\
\text { Chymotrypsin, } \\
\text { Neutrase, Papain, } \\
\text { Flavorase }\end{array}$ & $\begin{array}{l}\text { FRDEHKK } \\
\text { KHNRGDEF }\end{array}$ & [151] \\
\hline
\end{tabular}

1 The enzyme indicated in bold is the most effective of the enzymes to produce antioxidative activity/peptides

Table 2. Antioxidative capacity of plant protein-derived hydrolysates and peptides

scavenging activities as well transition metal chelating activities. Chen and coworkers [140] isolated 6 antioxidative peptide fragments from the digests of $\beta$-conglycinin, a main soybean protein component, by using protease $S$ from Bacillus sp. The antioxidant activity of the soybean hydrolysates, based on a linoleic acid oxidation system study, was attributed to the Leu-Leu-Pro-His-His peptide sequence [89, 93]. A potent antioxidant peptide, with inhibitory activity of lipid peroxidation, was isolated from soy protein isolate hydrolysed by 
Alcalase. Purification of peptide by ultrafiltration and chromatographic techniques enhanced the specific activity 67.9-fold compared to hydrolysate. The final potent antioxidant peptide contained hydrophobic amino acids and among them, Phe was especially abundant [141].

Pea and mung bean protein digests have been reported to possess antihypertensive activity in SHR [48, 142]. Mung bean protein hydrolysate prepared with alcalase decreased significantly SBP $(-30.8 \mathrm{mmHg})$ of SHR $6 \mathrm{~h}$ after single oral administration at a dose of 600 $\mathrm{mg} / \mathrm{ml}$. The blood pressure-lowering effect continued for at least $8 \mathrm{~h}$, and the blood pressure returned to initial levels at $12 \mathrm{~h}$ after administration [48]. Single administration of mung bean raw sprout extract (at dose of $600 \mathrm{mg} / \mathrm{kg}$ ) reduced significantly SBP $(-40 \mathrm{mmHg}) 6 \mathrm{~h}$ after administration. Plasma ACE activities in the treated rats also decreased $(0.007 \mathrm{Unit} / \mathrm{ml})$. Long-term intervention ( 1 month) test showed that blood pressure in the treated animals fluctuated according to the treatments. While raw sprout extract showed effective results after 1 week of intervention, dried sprout extracts did not have significant effects until 2 weeks [142]. Pea protein hydrolysate was made by thermolysin action followed by membrane filtration. Oral administration of the pea protein hydrolysate, containing $<3 \mathrm{kDa}$ peptides, to SHR at doses of 100 and $200 \mathrm{mg} / \mathrm{kg}$ body weight led to a lowering of SBP, with a maximum reduction of $19 \mathrm{mmHg}$ at $4 \mathrm{~h}$. In contrast, orally administered unhydrolysed pea protein isolate had no blood pressure reducing effect in SHR, suggesting that thermolysin hydrolysis may have been responsible for releasing bioactive peptides from the native protein [143]. Pea protein peptides from in vitro gastrointestinal digestion were observed to absorb poorly with in vitro model and the hypotensive effect was tested with intravenous administration [144].

\subsubsection{Cereals}

The seed storage proteins of wheat, barley, rye, and oats contain known ACE-inhibitory diand tripeptides in their primary structures. Barley and barley by-products extract possesses a biological activity such as free radical scavenging activity, tyrosinase, xanthin oxidase, and ACE-inhibition effect [145]. Hydrolysates of barley prolamin fraction exhibited the highest antioxidant and ACE-inhibitory activity compared to other protein fractions and protein isolate. Moreover, positive correlations were obtained between antioxidant and ACEinhibitory activity and the degree of hydrolysis of hydrolysed protein fractions and protein isolate [146].

The computer analysis of amino acid sequences of wheat gliadins made by means of BIOPEP database [147] showed the presence of fragments that are homological with the sequences regarded as antihypertensive peptides. They were: Leu-Gln-Pro $(\alpha-, \beta-$ and $\gamma-$ gliadins), Pro-Tyr-Pro ( $\alpha$-, $\beta$ - and $\gamma$-gliadins), Ile-Pro-Pro ( $\alpha$-and $\beta$-gliadins), Leu-Pro-Pro ( $\gamma$ gliadins) and Leu-Val-Leu ( $\gamma$-gliadins). Bioinformatic analysis of cereal proteins sequences revealed that particularly four tripeptides with known ACE-inhibitory activity, Leu-GlnPro, Val-Pro-Pro, Ile-Pro-Pro, and Leu-Leu-Pro, are frequently encrypted in the primary structure of rye secalin, wheat gluten, and barley hordein. Sourdoughs fermented with different strains showed different concentrations of Leu-Gln-Pro and Leu-Leu-Pro. These 
differences corresponded to strain-specific differences in endopeptidase (PepO) and aminopeptidase (PepN) activities. The highest levels of peptides Val-Pro-Pro, Ile-Pro-Pro, Leu-Gln-Pro, and Leu-Leu-Pro, 0.23, 0.71, 1.09, and $0.09 \mathrm{mmol} / \mathrm{kg}$ dry matter (DM), respectively, were observed in rye malt: gluten sourdoughs fermented with Lactobacillus reuteri TMW 1.106 and added protease [148]. Several clinical trials with hypertensive humans show a moderate but relatively consistent reduction of blood pressure upon consumption of the fermented milk products containing Val-Pro-Pro and Ile-Pro-Pro [88, 112]. Cheung and co-workers [149] used in silico approach to evaluate the potential of using oats as a protein source for generation of ACE-inhibitory peptides, and to screen for candidate enzymes to hydrolyse the oat protein for this purpose. It was found that thermolysin under high enzyme to substrate ratio (3\%) and short time (20 min) conditions produced strong and stable ACE-inhibitory activity.

Barley glutelin possess high hydrophobic amino acid content and enzymatic release by Alcalase produced peptides that had antioxidant capacity. Large size peptides possessed stronger DPPH scavenging activity and reducing power, whereas small-sized peptides were more effective in $\mathrm{Fe}^{2+}$ and hydroxyl radical scavenging activity [54]. Pepsin hydrolysis of byproduct of the wheat starch industry has shown antioxidant properties. Especially ultrafiltration produced fraction showed strong inhibition of the autoxidation of linoleic acid and scavenging activity of DPPH, superoxide and hydroxyl free radicals. The molecular weight distribution ranged from 0.1-1.7 $\mathrm{kDa}$ and high content of total hydrophobic amino acid was found in the active fraction [150]. Rice endosperm protein was, respectively, digested by five different protease treatments (Alcalase, chymotrypsin, Neutrase, Papain and Flavorase), and Neutrase produced the most desirable quality of antioxidant peptides. Two different peptides showing strong antioxidant activities were isolated from the hydrolysate using consecutive chromatographic methods. Especially, Phe-Arg-Asp-Glu-HisLys-Lys significantly inhibited lipid peroxidation in a linoleic acid emulsion system more effectively than $\alpha$-tocopherol [151].

The Alcalase-generated rice hydrolysate showed ACE-inhibitory activity with an IC 50 value of $0.14 \mathrm{mg} / \mathrm{ml}$. A potent ACE-inhibitory peptide with the amino acid sequence of Thr-Gln-ValTyr (IC50 of $18.2 \mu \mathrm{M}$ ) was isolated and identified from the hydrolysate. Single oral administration of the hydrolysate $(600 \mathrm{mg} / \mathrm{kg})$ and Thr-Gln-Val-Tyr $(30 \mathrm{mg} / \mathrm{kg})$ showed significantly decreased blood pressure in SHR, -25.6 and $-40 \mathrm{mmHg}$ SBP, respectively, after $6 \mathrm{~h}$ [152]. Three strong ACE-inhibitors with the Leu-Arg-Pro, Leu-Ser-Pro and Leu-Gln-Pro sequences were isolated from maize $\alpha$-zein hydrolysed with thermolysin. After intravenous administration of these peptides ( $30 \mathrm{mg} / \mathrm{kg}$ body weight), SBP was found to decrease up to a maximum of $15 \mathrm{mmHg}$ [31]. Moreover, a tripeptide (Ile-Val-Tyr) isolated from wheat germ hydrolysate reduced MAP of $19.2 \mathrm{mmHg}$ at dose of $5 \mathrm{mg} / \mathrm{ml}$ in SHR [153].

\section{Bioavailability}

Bioavailability is a major issue when establishing correspondence between in vitro and in vivo activities of bioactive peptides. The capacity to reach target organ in an active conformation determines the physiological effect of bioactive peptides. Various processes 
take place after oral administration of a bioactive peptide and need to be considered on the final activity. It's highly likely that antihypertensive reported peptide sequences are subjected to alteration before the final activity in vivo after the various steps, such as attack of gastrointestinal enzymes and brush border peptidases, absorption through the intestinal barrier, attack of intracellular peptidases in the transcellular absorption and plasma enzymes after the peptides have entered the circulation [58, 154]. Therefore, the different aspects of bioavailability of antihypertensive peptide sequences have attracted a growing interest in the last years. The possibility of modification or breakdown of peptides during the gastrointestinal digestion is one of the most important factors to be considered when evaluating potential food-derived peptides for promotion of human health. Various models have been implemented to simulate gastrointestinal digestion; static and dynamic models which both differ in enzymes applied and reaction conditions, such as agitation and duration. For instance, authors in references [155] and [47] utilized human digestive liquids to model digestion in vitro whereas several reports have concerned implementation of porcine enzyme mixtures [e.g. 60, 127, 132]. In addition to studying the resistance of antihypertensive peptide sequences against the digestive enzymes, the models have been utilized in order to produce bioactive peptides, plant derived ACE-inhibitory peptides among them. For instance pea, lentil, bean and chickpea proteins have been reported to release ACE-inhibitory peptides during in vitro digestion [40, 127, 132]. The digestive characteristics of commercial proteases mixtures are known to differ from those of human origin [155]. Zhu and co-workers [156] reported that the antioxidative activity of a zein hydrolysate, which had previously shown antioxidant activity in aqueous solutions and in food systems, was either decreased or improved during the course of in vitro digestion, depending on the enzymes encountered and the duration of hydrolysis. Thus, direct comparison of the results between the different models is difficult. A consensus concerning the basic parameters would be relevant in order to harmonize the various in vitro digestion models.

Study of intestinal absorption in vitro is another common aim when elucidating the bioavailability. It has been indicated that a small portion of bioactive peptides can pass the intestine barrier and although it is usually too small to be considered nutritionally important, it can present the biological effects in tissue level [157, 158]. Molecular size and structural properties, such as hydrophobicity, affect the major transport route for peptides [158]. Research findings indicate that peptides with 2-6 amino acids are absorbed more readily in comparison to protein and free amino acids. As the molecular weight of peptides increases, their chance to pass the intestinal barrier decreases. Peptides are transported by active transcellular transport or by passive process [159]. The absorption studies are commonly performed with the monolayer of intestinal cell lines, such as Caco-2 cells, simulating intestinal epithelium, and analysis of peptides and metabolites in serum after in vivo and clinical studies. Foltz et al. [160] investigated the transport of Ile-Pro-Pro and ValPro-Pro by using three different absorption models and demonstrated that these tri-peptides are transported in small amounts intact across the barrier of the intestinal epithelium. In another study, the absolute bioavailability of the tri-peptides in pigs was below $0.1 \%$, with an extremely short elimination half-life ranging from 5 to $20 \mathrm{~min}$ [161]. In humans, maximal 
plasma concentration did not exceed picomolar concentration [162]. Studies concerning absorption of plant derived peptides are rare, but milk-derived peptide Leu-His-Leu-ProLeu-Pro is an interesting example of a peptide with evaluation of bioavailability. This peptide resisted gastrointestinal simulation, but cellular peptidases digested the peptide to His-Leu-Pro-Leu-Pro before crossing Caco-2 cell monolayer [163, 164]. The degradation product, His-Leu-Pro-Leu-Pro, has been demonstrated to absorb in human intestine as it has been identified in human plasma after oral administration [165].

Fujita and colleagues [166] established a bioavailability factor in relation to antihypertensive activity and ACE inhibition mechanism. The classification is based on inhibitor type and substrate type, the possible conversion of peptides by ACE into peptides with weaker activity and pro-drug type inhibitors, or possible conversion of peptides into true inhibitors by ACE or gastrointestinal proteases. A delayed antihypertensive effect is characteristic for pro-drug type peptides as they need to degrade further to reach the final active form [167, 168]. For instance, flaxseed protein showed pro-drug type characteristics compared to hydrolysed cationic peptide fraction [126]. The protein fraction showed a delayed hypotensive effect in SHR comparable to captopril ( $3 \mathrm{mg} / \mathrm{kg}$ body weight) and the effect was more sustained than the effect of the digested peptide fraction. The slow-acting character of the protein fraction was expected since the digestion of the proteins. Anyhow, more research is needed to identify the active peptide sequences released in the digestive tract and to evaluate the bioavailability of these peptides.

It can be deduced due to the incomplete bioavailability of peptide following oral ingestion, a peptide with pronounced antioxidant activity in vitro may exert little or no activity in vivo. However, bypass routes which increase the chance of peptide absorption can diminish the problem and it is possible that in vivo antioxidant activity can be higher than in vitro activity. In such cases, bioactive peptides may display their biological functions by mechanisms other than what is applied in experiment. In addition, it has been suggested that the strong in vivo activity can be due to increased activity of peptides following their breakdown by gastrointestinal proteases [88].

The improvement and optimization of bioavailability of antihypertensive peptides have gained a great interest during the last decade. The improvement of limited absorption and stability of peptides has been a goal when evaluating their effectiveness. For example, some carriers interact with the peptide molecule to create an insoluble entity at low $\mathrm{pH}$, which later dissolves and facilitates intestinal uptake, by enhancing peptide transport over the non-polar biological membrane [169]. Bioavailability of bioactive tri-peptides (Val-Pro-Pro, Ile-Pro-Pro, Leu-Pro-Pro) was improved by administering them with a meal containing fibre, as compared to a meal containing no fibre. High methylated citrus pectin was used as a fibre [170]. Among drug delivery systems, emulsions have been used to enhance oral bioavailability or promoting absorption through mucosal surfaces of peptides and proteins [169]. Individually, various components of emulsions have been considered as candidates for improving bioavailability of peptides. Anyhow, it seems that no general strategy for improving bioavailability of antihypertensive peptides exists and due to the number of processes involved and different characteristics of peptides depending on the sequence each 
case must be studied. Many strategies are currently demonstrated for enhancing bioavailability [171], among them microencapsulation for controlled release of the active compounds, stabilization of the active molecules to improve transportation through the intestinal barrier and provide resistance against degradation, and development of highly stabile peptide analogues [172-174].

\section{Health benefits}

ACE-inhibitory peptides have been studied extensively in the past two decades and ACEinhibition is the main mechanism concerning bioactive peptides with proven antihypertensive effects. ACE is a constituent enzyme of the Renin-Angiotensin-Aldosterone System (RAAS), which is a crucial regulator in human physiology. It controls blood pressure, fluid and electrolyte balance and affects the heart, vasculature and kidney [2]. Among the food-derived ACE-inhibitory peptides milk-derived peptides are the most extensively studied. The relevance of vegetable proteins as a source of antihypertensive peptides is increasing and several in vivo studies performed in SHR have demonstrated that plant-derived ACE-inhibitory protein hydrolysates and peptides significantly reduce blood pressure, either after oral or intravenous administration. For instance, a clinical randomized, placebo-controlled crossover study was performed in order to elucidate further the antihypertensive potential of yam tuber dioscorins [175]. The dioscorin meal or placebo was intervened as a morning drink daily for five weeks, followed by a washout stage for one week and the trial was then crossed over for five weeks. The SBP and DBP values were decreased after the five weeks of dioscorin meal intervention. The clinical trial as well as the animal trials with dioscorin intervention suggests that the gastrointestinal digestion may produce antihypertensive peptides from the yam tuber dioscorins.

Furthermore, related to the RAAS, plant derived ACE-inhibitory peptides have been reported to possess inhibition activity against renin, the first and rate-determining enzyme in RAAS [2]. The inhibition of renin is being suggested as a major alternative in hypertension prevention. The first direct renin-inhibitor, aliskiren, is currently under phase III trials to evaluate its potential as an antihypertensive drug [176]. Thermolysin digest of pea protein decreased remarkably the renal expression of renin mRNA levels in vivo and lowered plasma levels of angiotensin II, thus the reduction in blood pressure in SHR and human subjects was likely due to the effects on the renal angiotensin system [143]. Peaderived peptides Ile-Arg, Lys-Phe and Glu-Phe showed strong inhibitions in vitro studies of ACE and renin [133] as well as ACE-inhibitory peptide fractions from flaxseed protein hydrolysates possessed inhibition also against renin [126, 177, 178].

Opioid receptors are involved in various physiological phenomenons, e.g. in the regulation of blood pressure and circulation, and these receptors are related to the antihypertensive properties of some food derived peptides. Other vasodilatory substances, such as ET-1, have also been suggested to be involved in the antihypertensive effects of food-derived peptides $[173,178,179]$. However, peptide sequences derived specifically from plant proteins inducing endothelial NO liberation have not been reported this far. A cationic Arg-rich 
peptide fraction from flaxseed, which possessed hypotensive effects in SHR, was suggested to mediate blood pressure through vasodilatory activity of NO synthesized from Arg. The observed effect might also be due to ACE- and renin-inhibition and in-depth research is needed to measure the renin and ACE protein levels and activities in SHR tissues and plasma and to specify the prior mechanism of antihypertensive action [44].

Calmodulin (CaM) -dependent cyclic nucleotide phosphodiesterase (CaMPDE) regulates a large variety of cellular functions and excessive levels of CaM and CaMPDE play important roles in many physiological conditions, symptoms of cardiovascular disease among them. Recently, food derived peptides capable to inhibit CaMPDE have been reported, flaxseed and pea protein derived peptides among them [125, 133, 178]. Oxidative stress is a crucial causative factor for the initiation and progression of hypertension and CVD. Increased production of ROS, such as $\mathrm{H} 2 \mathrm{O} 2$ and superoxide anion, reduced NO synthesis, and decreased bioavailability of antioxidants have been demonstrated in experimental and human hypertension. Diet rich in antioxidants can reduce blood pressure and thus, antioxidant properties of food-derived peptides may also affect on blood pressure regulation [180, 181]. Several food derived peptides have been reported to possess dual (ACE-inhibition and antioxidant) activity, among them plant protein derived hydrolysates of flaxseed [44, 55,182], rapeseed [47], potato [13] and yam [115, 116].

New mechanisms of action of antihypertensive peptides have been demonstrated in the recent years. The antihypertensive effect of a rapeseed derived tri-peptide rapakinin, was suggested to be mediated through other mechanism than ACE-inhibition [125]. Later on, different mechanisms were considered and the vasorelaxing activity of rapakinin was not blocked by eNOS inhibitor, while antagonists of IP and CCK1 receptor blocked the vasorelaxing effect of rapakinin significantly [128]. The results demonstrated that rapakinin relaxes the mesenteric artery of SHR through the PGI2-IP receptor followed by CCK pathway and the antihypertensive activity is mediated mainly by the PGI2-IP CCK-CCK1 receptor-dependent vasorelaxation. Moreover, inhibition of platelet-activating factor acetylhydrolase (PAF-AH) is suggested to play a crucial role in the hypertension prevention. PAF-AH is a circulatory enzyme secreted by inflammatory cells and it is involved in atherosclerosis. The discovery and application of natural PAF-AH into health promoting foods open up considerable potential [183].

\section{General conclusions}

The interest on foods possessing health-promoting or disease-preventing properties has been increasing. So far most of the studies on antihypertensive peptides have been done on milk protein-derived peptides. In fact, much work has been done with dietary antihypertensive peptides and evidence of their effect in animal and clinical studies. However, it has been highlighted that there is a huge potential for obtaining antihypertensive peptides from protein sources other than milk. Much work has been done on plant protein hydrolysates and their activity in vitro. So far only limited number of peptides has been identified from plant proteins. In addition very little is known on the 
activity of these hydrolysates and peptides in animal or in humans. These findings open up an interesting field aiming to revaluation of plant derived protein-rich by-products formed in food industry processes in remarkable amounts.

Certain aspects, such as identification of the active form of the peptides in the organism and the different mechanisms of action that contribute in the antihypertensive effect still need to be further investigated. Recent advances on specific analytical techniques enable to follow small amounts of the peptides or derivatives in complex matrices and biological fluids. This will allow performing the kinetic studies in model animals and humans. Similarly, identifying novel and more complex biomarkers of exposure and activity by advances in new disciplines such as nutrigenomic and nutrigenetic will open new ways to follow bioactivity in the organism. There is still poor knowledge on the resistance of peptides to gastric degradation, and low bioavailability of peptides has been observed. This reinforces the need of various strategies to improve the oral bioavailability of peptides.

More emphasis has been put on the legal regulation of the health claims attached to the products. Systematic approaches for review and assessment of scientific data have been developed by authorities around the world. The scientific evidence on the beneficial effects of the product should be enough detailed, extensive and conclusive for the use of a health claim in the functional food product labeling and marketing. First, it is necessary to identify and quantify the active sequences in the product. It is mandatory to monitor the hydrolytic or fermentative industrial production process as the antihypertensive peptides are only minor constituents in highly complex food matrices. Second, the antihypertensive effect in humans as well as the minimal dose needed to show the effect has to be proven in extensive investigations to fulfill the requirements of the legislation concerning functional foods. Besides being based on generally accepted scientific evidence, the claims should be well understood by the average consumer. Japan is the pioneer in the area of regulation of the health claims concerning food products. The concept of Foods for Specified Health Use (FOSHU) was established in 1991. In EU, the European Regulation on nutrition and health claims was established in January 2007 and the regulations are governed by European Food Safety Authority (EFSA).

\section{Author details}

Anne Pihlanto and Sari Mäkinen

MTT, Biotechnology and Food Research, Jokioinen, Finland

\section{References}

[1] World Health Organisation (2011) Cardiovascular Diseases (CVD’s). Fact sheet N³17.

[2] Lavoie JL, Sigmund CD (2003) Minireview: Overview of the renin-angiotensin system An endocrine and paracrine system. Endocrinol. 144: 2179-2189.

[3] Landmesser U, Spiekermann S, Dikalov S, Tatge H, Wilke R, Kohler C, Harrison DG, Hornig B, Drexler H (2002) Vascular oxidative stress and endothelial dysfunction in 
patients with chronic heart failure - Role of xanthine-oxidase and extracellular superoxide dismutase. Circulation 106: 3073-3078.

[4] Yao EH, Yu Y, Fukuda N (2006) Oxidative stress on progenitor and stem cells in cardiovascular diseases. Curr. pharm. biotechnol. 7: 101-108.

[5] Pihlanto A, Korhonen H (2003) Bioactive peptides and proteins. Adv. food res. 47: 175276.

[6] Guang C, Phillips RD (2009) Plant food-derived angiotensin I converting enzyme peptides. J. agric. food chem. 57: 5113-5120.

[7] Pihlanto A, Mäkinen S, Mattila P (2012) Potential health-promoting properties of potato-derived proteins, peptides and phenolic Compounds. In: Caprara C, editor. Potatoes: Production, Consumption and Health Benefits. Nova Publishers pp. 173-194.

[8] Heibges A, Salamini F, Gebhardt C (2003) Functional comparison of homologous members of three groups of Kunitz-type enzyme inhibitors from potato tubers (Solanum tuberosum L.). Mol. gen. genet. 269: 535-541.

[9] Kim J-Y, Park C-S, Hwang I, Cheong H, Nah J-W, Hahm K-S, Park Y (2009) Protease inhibitors from plants with antimicrobial activity. Int. j. mol. sci. 10: 2860-2872.

[10] Scherer GFE, Ryu SB, Wang XM, Matos AR, Heitz T (2010) Patatin-related phospholipase A: nomenclature, subfamilies and functions in plants. Trends plant sci. 15: 693-700.

[11] Bauw G, Nielsen HV, Emmersen J, Nielsen KL, Jorgensen M, Welinder KG (2006) Patatins, Kunitz protease inhibitors and other major proteins in tuber of potato cv. Kuras. FEBS J. 273: 3569-3584.

[12] Liu YW, Han CH, Lee MH, Hsu FL, Hou WC (2003) Patatin, the tuber storage protein of potato (Solanum tuberosum L.), exhibits antioxidant activity in vitro. J. agric. food chem. 51: 4389-4393.

[13] Pihlanto A, Akkanen S, Korhonen HJ (2008). ACE-inhibitory and antioxidant properties of potato (Solanum tuberosum). Food chem. 109: 104-112.

[14] Cheng Y, Xiong YL, Chen J (2010) Fractionation, separation, and identification of antioxidative peptides in potato protein hydrolysate that enhance oxidative stability of soybean oil emulsions. J. food sci.75: C760-C765.

[15] Hill AJ, Peikin SR, Ryan CA, Blundell JE (1990) Oral administration of proteinase inhibitor II from potatoes reduces energy intake in man. Physiol. behave. 48: 241-246.

[16] Bos C, Airinei G, Mariotti F, Benamouzig R, Bérot S, Evrard J, Fénart E, Tomé D, Gaudichon C (2007) The poor digestibility of rapeseed protein is balanced by its very high metabolic utilization in humans. J. nutr. 137: 594-600.

[17] Mariotti F, Hermier D, Sarrat C, Magné J, Fenart E, Evrard J, Tome D, Huneau JF (2008) Rapeseed protein inhibits the initiation of insulin resistance by a high-saturated fat, high-sucrose diet in rats. Br. j. nutr. 100: 984-991.

[18] Ooman DB (2001) Flaxseed as a functional food source. J. sci. food agric. 81: 889-894.

[19] Bazzano LA, He J, Ogden LG, Loria C, Vupputuri S, Myers L, Whelton PK (2001) Legume consumption and risk of coronary heart disease in US men and women. Arch. intern. med. 161: 2573-2578. 
[20] Reynolds K, Chin A, Lees KA, Nguyen A, Bujnowski D, He J (2006) A meta-analysis of the effect of soy protein supplementation on serum lipids. Am j. cardiol. 98: 633-640.

[21] Gibbs BF, Zougman A, Masse R, Mulligan C (2004) Production and characterization of bioactive peptides from soy hydrolysate and soy-fermented. Food res. int. 37: 123-131.

[22] Zhang JH, Tatsumi E, Ding CH, Li LT (2006) Angiotensin I-converting enzyme inhibitory peptides in Douchi, a Chinese traditional fermented soybean product. Food chem. 98: 551-557.

[23] Fan J, Hu X, Tan S, Zhang Y, Tatsumi E, Li L (2009) Isolation and characterisation of a novel angiotensin I-converting enzyme-inhibitory peptide derived from douchi, a traditional Chinese fermented soybean food. J. sci. food agric. 89: 603-608.

[24] Ibe S, Yoshida K, Kumada K, Tsurushin S, Furusho T, Otobe K (2009) Antihypertensive effects of natto, a traditional Japanese fermented food, in spontaneously hypertensive rats. Food sci. technol. res. 15: 199-202.

[25] Roy F, Boye JI, Simpson BK (2010) Bioactive proteins and peptides in pulse crops: Pea, chickpea and lentil. Food res. int. 43: 432-442.

[26] Aluko RE (2008) Determination of nutritional and bioactive properties of peptides in enzymatic pea, chickpea, and mung bean protein hydrolysates. J. AOAC int. 91: 947956.

[27] Ndiaye F, Tri Vuong, Duarte J, Aluko RE, Matar C (2012) Anti-oxidant, antiinflammatory and immunomodulating properties of an enzymatic protein hydrolysate from yellow field pea seeds. Eur. j. nutr. 51: 29-37.

[28] Arcan I, Yemenicioglu A (2010) Effects of controlled pepsin hydrolysis on antioxidant potential and fractional changes of chickpea proteins. Food res. int. 43: 140-147.

[29] Shewry PR, Halford NG (2002) Cereal seed storage proteins: structures, properties and role in grain utilization. J. exp. bot. 53: 947-958.

[30] Silano M, De Vincenzi M (1999) Bioactive antinutritional peptides derived from cereal prolamins: a review. Nahrung 43:175-184.

[31] Miyoshi S, Ishikawa H, Kaneko T, Fukui F, Tanaka H, Maruyama S (1991) Structures and activity of angiotensin-converting enzyme inhibitors in an alpha-zein hydrolysate. Agric. biol. chem. 55: 1313-1318.

[32] Kong X, Zhou H, Hua Y, Qian H (2008). Preparation of wheat gluten hydrolysates with high opioid activity. Eur. food res. technol. 227: 511-517.

[33] Takahashi M, Moriguchi S, Yoshikawa M, Sakasaki R (1994) Isolation and characterization of oryzatensin - a novel bioactive peptide with ileum-contracting and immunomodulating activities derived from rice albumin. Biochem. mol. biol. int. 33: 1151-1158.

[34] Calderón de la Barca AM, RuizSalazar RA, JaraMarini ME (2000) Enzymatic hydrolysis of soy protein to improve its amino acid composition and functional properties. J. food sci. 65: 246-253.

[35] Moure A, Domínguez H, Parajó JC (2005) Fractionation and enzymatic hydrolysis of soluble protein present in waste liquors from soy processing. J. agric. food chem. 53: $7600-7608$. 
[36] Yim MH, Lee JH (2000) Functional properties of fractionated soy protein isolates by proteases from Meju. Food sci. biotechnol. 9: 253-257.

[37] Kristinsson HG, Rasco BA (2000) Biochemical and functional properties of Atlantic salmon (Salmo salar) muscle hydrolyzed with various alkaline proteases. J. agric. food chem. 48: 657-666.

[38] Inouye K, Nakano K, Asaoka K, Yasukawa K (2009) Effects of thermal treatment on the coagulation of soy proteins induced by subtilisin Carlsberg. J agric. food chem. 57:71723.

[39] Wu J, Ding X (2002) Characterization of inhibition and stability of soy-protein-derived angiotensin I-converting enzyme inhibitory peptides. Food res. int. 35: 367-375.

[40] Barbana C, Boye JI (2010) Angiotensin I-converting enzyme inhibitory activity of chickpea and pea protein hydrolysates. Food res. int. 43: 1642-1649.

[41] Pedroche J, Yust MM, Giron-Calle J, Alaiz M, Millan F, Vioque J (2002) Utilisation of chickpea protein isolates for production of peptides with angiotensin I-converting enzyme (ACE)-inhibitory activity. J. sci. food. agric. 82: 960-965.

[42] Udenigwe CC, Aluko RE (2010) Antioxidant and angiotensin converting enzymeinhibitory properties of a flaxseed protein-derived high fischer ratio peptide mixture. J. agric. food chem. 58: 4762-4768.

[43] Yust MM, Pedroche J, Giron-Calle J, Alaiz M, Francisco M, Vioque J (2003) Production of ace inhibitory peptides by digestion of chickpea legumin with alcalase. Food chem. 81: 363-369.

[44] Udenigwe CC, Adebiyi AP, Doyen A, Li H, Bazinet L, Aluko RE (2012) Low molecular weight flaxseed protein-derived arginine-containing peptides reduced blood pressure of spontaneously hypertensive rats faster than amino acid form of arginine and native flaxseed protein. Food chem. 132: 468-475.

[45] Megias C, Pedroche J, Yust MDM, Alaiz M, Giron-Calle J, Millan F, Vioque J (2006) Affinity purification of angiotensin converting enzyme inhibitory peptides using immobilized ACE. J. agric. food chem. 54: 7120-7124.

[46] Wu J, Aluko RE, Muir AD (2008) Purification of angiotensin I-converting enzymeinhibitory peptides from the enzymatic hydrolysate of defatted canola meal. Food chem. 111: 942-950.

[47] Mäkinen S, Johansson T, Vegarud G, Pihlava J-M, Pihlanto A (2012) Angiotensin Iconverting enzyme inhibitory and antioxidant properties of rapeseed hydrolysates. J. funct. foods 4: 575-583.

[48] Li G, Shi Y, Liu H, Le G (2006) Antihypertensive effect of alcalase generated mung bean protein hydrolysates in spontaneously hypertensive rats. Eur. food res. technol. 222: 733-736.

[49] FitzGerald R, Meisel H (2000) Milk protein-derived peptide inhibitors of angiotensin-Iconverting enzyme. Br. j. nutr. 84: S33-S37.

[50] Makinen S, Kelloniemi J, Pihlanto A, Makinen K, Korhonen H, Hopia A, Valkonen JPT (2008) Inhibition of angiotensin converting enzyme I caused by autolysis of potato 
proteins by enzymatic activities confined to different parts of the potato tuber. J. agric. food chem. 56: 9875-9883.

[51] Pêna-Ramos EA, Xiong YL (2002) Antioxidant activity of soy protein hydrolyzates in a liposomial system. J. food sci. 67: 2952-2956

[52] Li Y, Jiang B, Zhang T, Mu W, Liu J (2008) Antioxidant and free radical scavenging activities of chickpea protein hydrolysate (CPH). Food chem. 106: 444-450.

[53] Dryakova A, Pihlanto A, Marnila P, Curda L, Korhonen HJT (2010) Antioxidant properties of whey protein hydrolysates as measured by three methods. Eur. food res. technol. 230: 865-874.

[54] Xia Y, Bamdad F, Gänzle M, Chen L (2012) Fractionation and characterization of antioxidant peptides derived from barley glutelin by enzymatic hydrolysis. Food chem. 134: 1509-1518.

[55] Udenigwe CC, Lu Y, Han C, Hou W, Aluko RE (2009) Flaxseed protein-derived peptide fractions: Antioxidant properties and inhibition of lipopolysaccharide-induced nitric oxide production in murine macrophages. Food chem. 116: 277-284.

[56] Suetsuna K, Chen JR (2002) Isolation and characterization of peptides with antioxidant activity derived from wheat gluten. Food sci. tehnol. res. 8: 227-230.

[57] Zhang T, Li Y, Miao M, Jiang B (2011) Purification and characterisation of a new antioxidant peptide from chickpea (Cicer arietium L.) protein hydrolysates. Food chem. 128: 28-33.

[58] Vermeirssen V, Van Camp J, Verstraete A, Verstraete W (2004) Bioavailability of angiotensin I converting enzyme inhibitory peptides. Br. j. nutr. 92: 357.

[59] Li C, Matsui T, Matsumoto K, Yamasaki R, Kawasaki T (2002) Latent production of angiotensin I-converting enzyme inhibitors from buckwheat protein. J. pept. sci. 8: 267274.

[60] Lo WMY, Li-Chan ECY (2005) Angiotensin I converting enzyme inhibitory peptides from in vitro pepsin-pancreatin digestion of soy protein. J. agric. food chem. 53: 33693376.

[61] Megías C, Yust MM, Pedroche J, Lquari H, Girón-Calle J, Alaiz M, Millán F, Vioque J (2004) Purification of an ACE inhibitory peptide after hydrolysis of sunflower (Helianthus annuus L.) protein isolates. J. agric. food chem. 52: 1928-1932.

[62] Vermeirssen V, van der Bent A, Van Camp J, van Amerongen A, Verstraete W (2004) A quantitative in silico analysis calculates the angiotensin I converting enzyme (ACE) inhibitory activity in pea and whey protein digests. Biochimie 86: 231-239.

[63] Boye JI, Roufik S, Pesta N, Barbana C (2010) Angiotensin I-converting enzyme inhibitory properties and SDS-PAGE of red lentil protein hydrolysates. LWT - Food sci. technol. 43: 987-991.

[64] Barbana C, Boye JI (2011) Angiotensin I-converting enzyme inhibitory properties of lentil protein hydrolysates: Determination of the kinetics of inhibition. Food chem. 127: 94-101.

[65] Mannheim A, Cheryan M (1990) Continuous hydrolysis of milk protein in a membrane reactor. J. food sci. 55: 381-385. 
[66] Wang Y-K, He H-L, Wang G-F, Wu H, Zhou B-C, Chen X-L, Zhang YZ (2010) Oyster (Crassostrea gigas) hydrolysates produced on a plant scale have antitumor activity and immunostimulating effects in BALB/c mice. Mar. drugs 8:255-68.

[67] Chiang WE, Cordle CT, Thomas RL (1995) Casein hydrolysate produced using a formed-in-place membrane reactor. J. food sci. 60: 1349-1352.

[68] Guérard F (2007). Enzymatic methods for marine by-products recovery. In: Shahidi F editor. Maximizing the value of marine by-products. Campridge: Woodward Publishing Limited pp. 107-143.

[69] Chiang WD, Tsou MJ, Tsai ZY, Tsai TC (2006) Angiotensin I-converting enzyme inhibitor derived from soy protein hydrolysate and produced by using membrane reactor. Food chem. 98: 725-732.

[70] Korhonen H, Pihlanto A (2003) Food-derived bioactive peptides - Opportunities for designing future foods. Curr. pharm. design 9: 1297-1308.

[71] Virtanen T, Pihlanto A, Akkanen S, Korhonen H (2007) Development of antioxidant activity in milk whey during fermentation with lactic acid bacteria. J. appl. microbiol. 102: 106-115.

[72] Pihlanto A, Virtanen T, Korhonen H (2010) Angiotensin I converting enzyme (ACE) inhibitory activity and antihypertensive effect of fermented milk. Int. dairy j. 20: 3-10.

[73] Hernández-Ledesma B, Miralles B, Amigo L, Ramos M, Recio, I (2005) Identification of antioxidant and ACE-inhibitory peptides in fermented milk. J. sci. food agric. 85: 10411048.

[74] Pihlanto A, Johansson T, Mäkinen S (2012) Inhibition of angiotensin I-converting enzyme and lipid peroxidation by fermented rapeseed and flaxseed meal. Eng. life sci. DOI: 10.1002/elsc.201100137.

[75] Okamoto A, hanagata H, Matsumoto E, kawamura Y, Koizumi Y, Yanagida F (1995) Angiotensin I-converting enzyme inhibitory peptides isolated from tofuyo fermented soybean food. Biosci. biotech. biochem 59: 1147-1149.

[76] Kuba M, Tanaka K, Tawata S, Takeda Y, Yasuda M (2003) Angiotensin I-converting enzyme inhibitory peptides isolated from tofuyo fermented soybean food. Biosci. biotech. biochem. 67: 1278-1283.

[77] Li F-J, Yin L-J, Cheng Y-Q, Saito M, Yamaki K, Li L-T (2010) Angiotensin I-converting enzyme inhibitory activities of extracts from commercial chinese style fermented soypaste. JARQ 44:167-172.

[78] Tsai JS, Lin YS, Pan BS, Chen TJ (2006) Antihypertensive peptides and $\gamma$-aminobutyric acid from prozyme 6 facilitated lactic acid bacteria fermentation of soymilk. Process biochem. 41: 1282-1288.

[79] Iwai K, Nakaya N, Kawasaki Y, Matsue H (2002) Inhibitory effect of natto, a kind of fermented soybeans, on LDL oxidation in vitro. J. agric. food chem. 50: 3592-3596.

[80] Wang D, Wang L, Zhu F, Zhu J, Chen XD, Zou L, Saito, M, Li L (2008) In vitro and in vivo studies on the antioxidant activities of the aqueous extracts of Douchi (a traditional Chinese salt-fermented soybean food). Food chem. 107:1421-1428. 
[81] Natesh R, Schwager SLU, Sturrock ED, Acharya KR (2003) Crystal structure of the human angiotensin-converting enzyme lisonopril complex. Nature 421: 551-554.

[82] Ondetti MA, Rubin B, Cushman DW (1977) Design of specific inhibitors of angiotensinconverting enzyme: new class of orally active antihypertensive agents. Science 196: 441444.

[83] Cheung HS, Wang FL, Ondetti MA, Sabo EF, Cushman DW (1980) Binding of peptide substrates and inhibitors of angiotensin-converting enzyme: importance of the $\mathrm{COOH}$ terminal dipeptide sequence. J biol. chem. 255: 401-407.

[84] Ariyoshi Y (1993) Angiotensin-converting enzyme inhibitors derived from food proteins. Trends food sci. technol. 4:139-144.

[85] Pripp AH, Isaksson T, Stepaniak L, Sorhaug T (2004) Quantitative structure-activity relationship modelling of ACE-inhibitory peptides derived from milk proteins. Eur. food res. technol. 219: 579-583.

[86] Moure A, Domínguez H, Parajó JC (2006) Antioxidant properties of ultrafiltration recovered soy protein fractions from industrial effluents and their hydrolysates. Process biochem. 41: 447-456.

[87] Rajapakse N, Mendis E, Jung WK, Je JY, Kim SK (2005) Purification of a radical scavenging peptide from fermented mussel sauce and its antioxidant properties. Food res. int. 38: 175-182.

[88] Erdmann K, Cheung BWY, Schröder H (2008) The possible roles of food derived bioactive peptides in reducing the risk of cardiovascular disease. J. nutr. biol. 19: 643654.

[89] Chen HM, Muramoto K, Yamauchi F, Fujimoto K, Nokihara K (1998) Antioxidative properties of histidine-containing peptides designed from peptide fragments found in the digests of a soybean protein. J. agric. food chem. 46: 49-53.

[90] Pihlanto A (2006) Antioxidative peptides derived from milk proteins. Int. dairy j. 16: 1306-1314.

[91] Chan KM, Decker EA (1994) Endogenous muscle antioxidants. Crit. rev. food. sci. 34: 403-426.

[92] Qian ZJ, Jung WK, Kim SK (2008) Free radical scavenging activity of a novel antioxidative peptide purified from hydrolysate of bullfrog skin, Rana catesbeiana Shaw. bioresource technol. 99: 1690-1698.

[93] Chen HM, Muramoto K, Yamauchi F, Nokihara K (1996) Antioxidant activity of designed peptides based on the antioxidative peptide isolated from digests of a soybean protein. J. agric. food chem. 44: 2619-2623.

[94] Saito K, Jin DH, Ogawa T, Muramoto K, Hatakeyama E, Yasuhara T, Nokihara K (2003) Antioxidative properties of tripeptide libraries prepared by the combinatorial chemistry. J. agric. food chem. 51: 3668-3674.

[95] Nagasawa T, Yonekura T, Nishizawa N, Kitts DD (2001) In vitro and in vivo inhibition of muscle lipid and protein oxidation by carnosine. Mol. cell. biochem. 225: 29-34. 
[96] Hernández-Ledesma B, Davalos A, Bartolome B, Amigo L (2005) Preparation of antioxidant enzymatic hydrolysates from a-lactalbumin and b-lactoglobulin. Identification of active peptides by HPLC-MS/MS. J. agric. food chem. 53: 588-593.

[97] Cushman DW, Cheung HS (1971) Spectrophotometric assay and properties of the angiotensin converting enzyme of rabbit lung. Biochem. pharmacol. 20: 1637.

[98] Vermeirssen V, Van Camp J, Verstraete W (2002) Optimisation and validation of an angiotensin-converting enzyme inhibition assay for the screening of bioactive peptides. J. biochem. biophys. methods 51: 75 .

[99] Li GH, Liu H, Shi Y-H, Le GW (2005) Direct spectrophotometric measurement of angiotensin I-converting enzyme inhibitory activity for screening bioactive peptides. J. pharm. biomed. anal. 37: 219.

[100] Shalaby SM, Zakora M, Otte J (2006) Performance of two commonly used angiotensinconverting enzyme inhibition assays using synthetic peptide substrates. J. dairy res. 73: 178.

[101] Doig MT, Smiley JW (1993) Direct injection assay of angiotensin-converting enzyme by high-performance liquid-chromatography using a shielded hydrophobic phase column. J. chrom. biomed. appl. 613: 145.

[102] Hyun C, Shin H (2000) Utilization of bovine blood plasma proteins for the production of angiotensin I converting enzyme inhibitory peptides, Process biochem. 36: 65-71.

[103] Holmquist B, Bunning P, Riordan J (1979) Continuous spectrophotometric assay for angiotensin converting enzyme. Anal. biochem. 95: 540-548.

[104] Carmel A, Yaron A (1978) An intramolecularly quenched fuorescent tripeptide as a fuorogenic substrate of angiotensin-I-converting enzyme and of bacterial dipeptidyl carboxypeptidase. Eur. j. biochem. 87: 265.

[105] Sentandreu MA, Toldrá F (2006) A rapid, simple and sensitive fuorescence method for the assay of angiotensin-I converting enzyme. Food chem. 97: 546.

[106] Cao G, Prior RL (1998) Comparison of different analytical methods for assessing total antioxidant capacity of human serum. Clin. chem. 44: 1309-1315.

[107] Re R, Pellegrini N, Proteggente A, Pannala A, Yang M, Rice- Evans C (1999) Antioxidant activity applying an improved ABTS radical cation decolorization assay. Free radical bio. med. 26: 1231-1237.

[108] Verma S, Buchanan MR, Anderson TJ (2003) Endothelial function testing as a biomarker of vascular disease. Circulation 108: 2054-9.

[109] Liu RH, Finley J (2005) Potential cell culture models for antioxidant research. J. agric. food chem. 53: 4311-4314.

[110] Elisia I, Kitts DD (2008) Anthocyanins inhibit peroxy radical-induced apoptosis in Caco-2 cells. Mol. cell. biochem. 312: 139-145.

[111] Wolfe KL, Liu RH (2007) Cellular antioxidant activity (CAA) assay for assessing antioxidants, foods, and dietary supplements. J. agric. food chem.. 55: 8896-8907.

[112] Fitzgerald RJ, Murray BA, Walsh DJ (2004) Hypotensive peptides from milk proteins. J. nutr. 134: 980-988. 
[113] Hsu F, Lin Y, Lee M, Lin C, Hou W (2002) Both dioscorin, the tuber storage protein of yam (Dioscorea alata cv. Tainong No. 1), and its peptic hydrolysates exhibited angiotensin converting enzyme inhibitory activities. J. agric. food chem. 50: 61096113.

[114] Lee M, Lin Y, Lin Y, Hsu F, Hou W (2003) The mucilage of yam (Dioscorea batatas Decne) tuber exhibited angiotensin converting enzyme inhibitory activities. Bot. bull. acad. sinica 44: 267-273.

[115] Nagai T, Suzuki N, Nagashima T (2007) Autolysate and enzymatic hydrolysates from yam (Dioscorea opposita Thunb.) tuber mucilage tororo have antioxidant and angiotensin I-converting enzyme inhibitory activities. J. food agric. environ. 5: 39-43.

[116] Nagai T, Suzuki N, Tanoue Y, Kai N, Nagashima T (2007) Antioxidant and antihypertensive activities of autolysate and enzymatic hydrolysates from yam (Dioscorea opposita Thunb.) ichyoimo tubers. J. food agric. environ. 5: 64-68.

[117] Lacaille-Dubois MA, Franck U, Wagner H (2001) Search for potential angiotensin converting enzyme (ACE)-inhibitors from plants. Phytomedicine 8: 47-52.

[118] Huang G, Lu T, Chiu C, Chen H, Wu C, Lin Y, Hsieh W, Liao J, Sheu M, Lin Y (2011) Sweet potato storage root defensin and its tryptic hydrolysates exhibited angiotensin converting enzyme inhibitory activity in vitro. Bot. stud. 52: 257-264.

[119] Huang G, Chen H, Susumu K, Wu J, Hou W, Wu C, Sheu M, Huang S, Lin Y (2011) Sweet potato storage root thioredoxin $\mathrm{h} 2$ and their peptic hydrolysates exhibited angiotensin converting enzyme inhibitory activity in vitro. Bot. stud. 52: 15-22

[120] Huang G, Ho Y, Chen H, Chang Y, Huang S, Hung H, Lin Y (2008) Sweet potato storage root trypsin inhibitor and their peptic hydrolysates exhibited angiotensin converting enzyme inhibitory activity in vitro. Bot. stud. 49: 101-108.

[121] Ishiguro K, Sameshima Y, Kume T, Ikeda K, Matsumoto J, Yoshimoto M (2012) Hypotensive effect of a sweet potato protein digest in spontaneously hypertensive rats and purification of angiotensin I-converting enzyme inhibitory peptides. Food chem. 131: 774-779.

[122] Lin C, Lin S, Lin Y, Hou W (2006) Effects of tuber storage protein of yam (Dioscorea alata cv. Tainong No. 1) and its peptic hydrolyzates on spontaneously hypertensive rats. J. sci. food agric. 86: 1489-1494.

[123] Liu Y, Lin Y, Liu D, Han C, Chen C, Fan M, Hou W (2009) Effects of different types of yam (Dioscorea alata) products on the blood pressure of spontaneously hypertensive Rats. Biosci. biotech. biochem. 73: 1371-1376.

[124] Iwai K, Matsue H (2007) Ingestion of Apios americana Medikus tuber suppresses blood pressure and improves plasma lipids in spontaneously hypertensive rats. Nutr. res. 27: 218-224.

[125] Marczak E, Usui H, Fujita H, Yang Y, Yokoo M, Lipkowski A, Yoshikawa M (2003) New antihypertensive peptides isolated from rapeseed. Peptides 24: 791-798.

[126] Udenigwe CC, Lin YS, Hou WC, Aluko RE (2009) Kinetics of the inhibition of renin and angiotensin I-converting enzyme by flaxseed protein hydrolysate fractions. J. funct. foods 1: 199-207. 
[127] Marambe HK, Shand PJ, Wanasundara, JPD (2011) Release of angiotensin I-converting enzyme inhibitory peptides from flaxseed (Linum usitatissimum L.) protein under simulated gastrointestinal digestion. J. agric. food chem. 59: 9596-9604.

[128] Yamada Y, Iwasaki M, Usui H, Ohinata K, Marczak ED, Lipkowski, AW, Yoshikawa M (2010) Rapakinin, an anti-hypertensive peptide derived from rapeseed protein, dilates mesenteric artery of spontaneously hypertensive rats via the prostaglandin IP receptor followed by CCK1 receptor. Peptides 31: 909-914.

[129] Marczak, E. D., Ohinata, K., Lipkowski, A. W., \& Yoshikawa, M. (2006). Arg-Ile-Tyr (RIY) derived from rapeseed protein decreases food intake and gastric emptying after oral administration in mice. Peptides 27: 2065-2068.

[130] Yamada Y, Ohinata K, Lipkowski AW, Yoshikawa M (2011) Rapakinin, Arg-Ile-Tyr, derived from rapeseed napin, shows anti-opioid activity via the prostaglandin IP receptor followed by the cholecystokinin CCK2 receptor in mice. Peptides 32: 281-285.

[131] Akıllıglu HG, Karakaya, S (2009) Effects of heat treatment and in vitro digestion on the angiotensin converting enzyme inhibitory activity of some legume species. Eur. food res. technol. 229: 915-921.

[132] Vermeirssen V, Van Camp J, Decroos K, Van Wijmelbeke L, Verstraete W (2003) The impact of fermentation and in vitro digestion on the formation of angiotensin-Iconverting enzyme Inhibitory activity from pea and whey protein. J. dairy. sci. 86: 429438.

[133] Li H, Aluko RF (2010) Identification and inhibitory properties of multifunctional peptides from pea protein hydrolysate. J. agric. food chem. 58: 11471-11476.

[134] Lo WMY, Farnworth ER, Li-Chan ECY (2006) Angiotensin I-converting enzyme inhibitory activity of soy protein digests in a dynamic model system simulating the upper gastrointestinal tract. J. food. sci. 71: S231-S237.

[135] Pownall TL, Udenigwe CC, Aluko RE (2010) Amino acid composition and antioxidant properties of pea seed (Pisum sativum L.) enzymatic protein hydrolysate fractions. J. agric. food chem. 58: 4712-4718.

[136] Pownall TL, Udenigwe CC, Aluko RE (2011) Effects of cationic property on the in vitro antioxidant activities of pea protein hydrolysate fractions. Food res. int. 44: 10691074.

[137] Li Y, Jiang B, Zhang T, Mu W, Liu J (2008) Antioxidant and free radical-scavenging activities of chickpea protein hydrolysate (CPH). Food chem. 106: 444-450.

[138] Liu JR, Chen MJ, Lin CW (2005) Antimutagenic and antioxidant properties of milkkefir and soymilk-kefir. J. agric. food chem 53: 2467-2474.

[139] Zhang L, Lia J, Zhoub K (2010) Chelating and radical scavenging activities of soy protein hydrolysates prepared from microbial proteases and their effect on meat lipid peroxidation. Bioresource technology, 101: 2084-2089.

[140] Chen HM, Muramoto K, Yamauchi F. 1995. Structural analysis of antioxidant peptides from soybean b-conglycinin. J Agric Food Chem 43:574-578. 
[141] Park SY, Lee JS, Baek HH, Lee HG (2010) Purification and characterization of antioxidant peptides from soy protein hydrolysate. J. food biochem.34:120-134

[142] Hsu GW, Lu Y, Chang S, Hsu S (2011) Antihypertensive effect of mung bean sprout extracts in spontaneously hypertensive rats. J. food biochem. 35: 278-288.

[143] Li H, Prairie N, Udenigwe CC, Adebiyi AP, Tappia PS, Aukema HM, Jones PJH, Aluko RE (2011) Blood pressure lowering effect of a pea protein hydrolysate in hypertensive rats and humans. J. agric. food chem. 59: 9854-9860.

[144] Vermeirssen V, Augustijns P, Morel N, Van Camp J, Opsomer A, Verstraete W (2005) In vitro intestinal transport and antihypertensive activity of ACE inhibitory pea and whey digests. Int. j. food sci. nutr. 56: 415-430.

[145] Lee NY, Kim Y, Choi I, Cho S, Hyun J, Choi J, Park K, Kim K, Lee M (2010) Biological activity of barley (Hordeum vulgare L.) and barley byproduct extracts. Food sci. biotechnol. 19: 785-791.

[146] Aludatt MH, Ereifej K, Abou-zaitoun A, Al-Rababah M, Almajwal A, Rababeh T, Yang W (2012) Oxidant, anti-diabetic and anti-hypertensive effects of extracted phenolics and hydrolyzed peptides from barley protein fraction. Int. j. food prop. 15: 781-795.

[147] Iwaniak A, Dziuba B (2009) Motifs with potential physiological activity in food proteins -Biopep database. Acta Scientiarum Polonorum: Technologia Alimentaria 8: 59-85.

[148] Ying Hu, Stromeck A, Loponen J, Lopes-Lutz D, Schieber A, Gänzle MG (2011) LCMS/MS Quantification of bioactive angiotensin I-converting enzyme inhibitory peptides in rye malt sourdoughs. J. agric. food chem. 59: 11983-11989.

[149] Cheung IWY, Nakayama S, Hsu MNK, Samaranayaka AGP, Li-Chan ECY (2009) Angiotensin-I converting enzyme inhibitory activity of hydrolysates from oat (Avena sativa) proteins by in silico and in vitro analyses. J agric. food chem. 57: 9234-9242.

[150] Kong X, Zhou H, Hua Y (2008) Preparation and antioxidant activity of wheat gluten hydrolysates (WGHs) using ultrafiltration membranes. J sci. food agric. 88: 920-926.

[151] Zhang J, Zhang H, Wang L, Guo X, Wang X, Yao H (2010) Isolation and identification of antioxidative peptides from rice endosperm protein enzymatic hydrolysate by consecutive chromatography and MALDI-TOF/TOF MS/MS. Food chem. 119: 226-234.

[152] Li GH, Qu MR, Wan JZ, You JM (2007) Antihypertensive effect of rice protein hydrolysate with in vitro angiotensin I-converting enzyme inhibitory activity in spontaneously hypertensive rats. Asia pa. j. clin. nutr. 16: 275-280.

[153] Matsui T, Li CH, Tanaka T, Maki T, Osajima Y, Matsumoto K (2000) Depressor effect of wheat germ hydrolysate and its novel angiotensin I-converting enzyme inhibitory peptide, Ile-Val-Tyr, and the metabolism in rat and human plasma. Biol. pharm. bull. 23: 427-431.

[154] De Leo F, Panarese S, Gallerani R, Ceci LR (2009) Angiotensin converting enzyme (ACE) inhibitory peptides: production and implementation of functional food. Curr. pharm. design 15: 3622-3643. 
[155] Eriksen EK, Holm H, Jensen E, Aaboe R, Devold TG, Jacobsen M, Vegarud GE (2010) Different digestion of caprine whey proteins by human and porcine gastrointestinal enzymes. Br. j. nutr. 104: 374-381.

[156] Zhu L, Chen J, Tang X, Xiong YL (2008) Reducing, radical scavenging, and chelation properties of in vitro digests of alcalase-treated zein hydrolysate. J. agric. food chem. 56: 2714-2721.

[157] Gardner MLG (1988) Gastrointestinal absorption of intact proteins. Annu. rev. nutr. 8: 329-350.

[158] Gardner MLG (1998) Transmucosal passage on intact peptides in mammalian metabolism. In: Grimble GK, Backwell FRG, editors. Tissue utilization and clinical targeting. London: Portland Press Ltd.

[159] Shimizu M, Tsunogai M, Arai S (1997) Transepithelial transport of oligopeptides in the human intestinal cell, Caco2. Peptides 18: 681-687.

[160] Foltz M, Cerstiaens A, van Meensel A, Mols R, van der Pijl PC, Duchateau GSMJE, Augustijns P (2008) The angiotensin converting enzyme inhibitory tripeptides Ile-ProPro and Val-Pro-Pro show increasing permeabilities with increasing physiological relevance of absorption models. Peptides 29: 1312-1320.

[161] van der Pijl PC, Kies AK, Ten Have GA, Duchateau GS, Deutz NE (2008) Pharmacokinetics of proline-rich tripeptides in the pig. Peptides 29: 2196-2202.

[162] Foltz M, Meynen EE, Bianco V, van Platerink C, Koning TMMG, Kloek J (2007) Angiotensin converting enzyme inhibitory peptides from a lactotripeptide-enriched milk beverage are absorbed intact into the circulation. J. nutr. 137: 953-958.

[163] Quiros A, Davalos A, Lasuncion MA, Ramos M, Recio I (2008) Bioavailability of the antihypertensive peptide LHLPLP: Transepithelial flux of HLPLP. Int. dairy j. 18: 279286.

[164] Quiros A, del Mar Contreras M, Ramos M, Amigo L, Recio I (2009) Stability to gastrointestinal enzymes and structure-activity relationship of beta-casein-peptides with antihypertensive properties. Peptides 30: 1848-1853.

[165] van Platerink C, Janssen H, Horsten R, Haverkamp J (2006) Quantification of ACE inhibiting peptides in human plasma using high performance liquid chromatographymass spectrometry. J. chromatogr. B 830: 151-157.

[166] Fujita H, Yokoyama K, Yoshikawa M (2000) Classification and antihypertensive activity of angiotensin I-converting enzyme inhibitory peptides derived from food proteins. J. food sci. 65: 564-569.

[167] Zhao Y, Li B, Dong S, Liu Z, Zhao X, Wang J, Zeng M (2009) A novel ACE inhibitory peptide isolated from Acaudina molpadioidea hydrolysate. Peptides 30: 1028-1033.

[168] Muguruma M, Ahhmed AM, Katayama K, Kawahara S, Maruyama M, Nakamura T (2009) Identification of pro-drug type ACE inhibitory peptide sourced from porcine myosin B: Evaluation of its antihypertensive effects in vivo. Food chem. 114: 516-522.

[169] Shaji J, Patole V (2008) Protein and peptide drug delivery: Oral approaches. J. pharm. sci. 70: 269-277. 
[170] Kies AK, Van Der Pijl P (2012) Peptide availability. USA Patent Application 20120040895.

[171] Nestor JJ Jr. (2009) The medicinal chemistry of peptides. Curr. med. chem. 16: 43994418.

[172] Yamada Y, Matoba N, Usui H, Onishi K, Yoshikawa M (2002) Design of a highly potent anti-hypertensive peptide based on ovokinin(2-7). Biosci. biotechn. biochem. 66: 1213-1217.

[173] Matoba N, Yamada Y, Usui H, Nakagiri R, Yoshikawa H (2001) Designing potent derivatives of ovokinin(2-7), an anti-hypertensive peptide derived from ovalbumin. Biosci. biotechn. biochem. 65: 736-739.

[174] Gomez-Guillen MC, Gimenez B, Lopez-Caballero ME, Montero MP (2011) Functional and bioactive properties of collagen and gelatin from alternative sources: A review. Food hydrocolloids 25: 1813-1827.

[175] Liu D, Liang H, Han C, Lin S, Chen C, Fan M, Hou W (2009) Feeding trial of instant food containing lyophilised yam powder in hypertensive subjects. J. sci. food agric. 89: 138-143.

[176] Peach MJ (1997) Renin-angiotensin system: biochemistry and mechanism of action. Physiol. rev. 57: 313-370.

[177] Gradman A, Schmieder R, Lins R, Nussberger J, Chiang Y, Bedigian, M (2005) Aliskiren, a novel orally effective renin inhibitor, provides dose-dependent antihypertensive efficacy and placebo-like tolerability in hypertensive patients. Circulation 111: 1012-1018.

[178] Udenigwe CC, Aluko RE (2012) Multifunctional cationic peptide fractions from flaxseed protein hydrolysates. Plant food hum. nutr. 67: 1-9.

[179] Erdmann K, Grosser N, Schipporeit K, Schroeder H (2006) The ACE inhibitory dipeptide Met-Tyr diminishes free radical formation in human endothelial cells via induction of heme oxygenase-1 and ferritin. J. nutr. 136: 2148-2152.

[180] Touyz R (2004) Reactive oxygen species, vascular oxidative stress, and redox signaling in hypertension - What is the clinical significance? Hypertension 44: 248-252.

[181] Akpaffiong M, Taylor A (1998) Antihypertensive and vasodilator actions of antioxidants in spontaneously hypertensive rats. Am. j. hyp. 11: 1450-1460.

[182] Marambe PWMLHK, Shand PJ, Wanasundara JPD (2008) An in-vitro investigation of selected biological activities of hydrolysed flaxseed (Linum usitatissimum L.) proteins. J. am. oil chem. soc. 85: 1155-1164.

[183] Fitzgerald C, Gallagher E, Tasdemir D, Hayes M (2011) Heart health peptides from macroalgae and their potential use in functional foods. J. agric. food chem. 59: 68296836.

[184] Nakahara T, Sano A, Yamaguchi H, Sugimoto K, Chikata H, Kinoshita E, Uchida R (2010) Antihypertensive effect of peptide-enriched soy sauce-like seasoning and identification of its angiotensin I-converting enzyme inhibitory substances. J. agric. food chem.58: 821-827. 
[185] Nogata Y, Nagamine T, Sekiya K (2011) Antihypertensive effect of angiotensin Iconverting enzyme inhibitory peptides derived from wheat bran in spontaneously hypertensive rats. J. jpn. soc. food sci. technol. 58: 67-70.

[186] Nogata Y, Nagamine T, Yanaka M, Ohta, H (2009) Angiotensin I converting enzyme inhibitory peptides produced by autolysis reactions from wheat bran. J. agric. food chem. 57: 6618-6622. 